\title{
Preservation potential of ancient plankton DNA in Pleistocene marine sediments
}

\author{
A. C. BOERE, ${ }^{1}$ W. I. C. RIJPSTRA, ${ }^{1}$ G. J. DE LANGE, ${ }^{2}$ J. S. SINNINGHE DAMSTÉ ${ }^{1,2}$ AND \\ M. J.L. COOLEN ${ }^{1,3}$ \\ ${ }^{I}$ Department of Marine Organic Biogeochemistry, NIOZ Royal Netherlands Institute for Sea Research, Den Burg, The Netherlands \\ ${ }^{2}$ Faculty of Earth Sciences, Utrecht Unipersity, Utrecht, The Netherlands \\ ${ }^{3}$ Department of Marine Chemistry and Geochemistry, Woods Hole Oceanographic Institution, Woods Hole, MA, USA
}

\begin{abstract}
Recent studies have shown that ancient plankton DNA can be recovered from Holocene lacustrine and marine sediments, including from species that do not leave diagnostic microscopic fossils in the sediment record. Therefore, the analysis of this so-called fossil plankton DNA is a promising approach for refining paleoecological and paleoenvironmental information. However, further studies are needed to reveal whether DNA of past plankton is preserved beyond the Holocene. Here, we identified past eukaryotic plankton members based on 185 rRNA gene profiling in eastern Mediterranean Holocene and Pleistocene sapropels S1 ( 9 ka), S3 ( $80 \mathrm{ka}$ ), S4 ( $\sim 105 \mathrm{ka})$, and S5 ( 125 ka). The majority of preserved $\sim 400$ - to 500-bp-long 185 rDNA fragments of microalgae that were studied in detail (i.e. from haptophyte algae and dinoflagellates) were found in the youngest sapropel S1, whereas their specific lipid biomarkers (long-chain alkenones and dinosterol) were also abundant in sediments deposited between 80 and $124 \mathrm{ka}$ BP. The late-Pleistocene sediments mainly contained eukaryotic DNA of marine fungi and from terrestrial plants, which could have been introduced via the river Nile at the time of deposition and preserved in pollen grains. A parallel analysis of Branched and Isoprenoid Tetraethers (i.e. BIT index) showed that most of the organic matter in the eastern Mediterranean sediment record was of marine (e.g. pelagic) origin. Therefore, the predominance of terrestrial plant DNA over plankton DNA in older sapropels suggests a preferential degradation of marine plankton DNA.
\end{abstract}

Received 10 January 2011; accepted 20 July 2011

Corresponding author: M. J. L. Coolen. Tel.: +1-508-289-2931; fax: +1-508-457-2164; e-mail address: mcoolen@whoi.edu

\section{INTRODUCTION}

The reconstruction of marine and lacustrine plankton is typically based on the analysis of microscopic remains of (planktonic) species such as diatoms (Kemp et al., 1999), coccolithophorid algae (Castradori, 1993), cyst-forming dinoflagellates (dinocysts) (Marret \& Zonneveld, 2003), and foraminifera (Principato et al., 2006) or geochemical analysis of characteristic molecules that are preserved in the geological record, so-called lipid biomarkers, or chemical fossils (Peters et al., 2005; Volkman et al., 1998). However, microscopic remains are rarely produced by all species of a taxonomic group [e.g. calcifying vs. noncalcifying haptophyte algae (Sáez et $a l ., 2004)$ ], and lipid biomarkers are often diagnostic only at higher taxonomic levels (Volkman et $a l ., 1998$ ).

In recent years, the analysis of ancient plankton-derived DNA preserved in marine or lacustrine sediments (i.e. fossil plankton DNA) has provided valuable information for refining reconstructions environmental conditions and, pice persa, the impact of climate-induced hydrologic and environmental changes on past plankton succession dynamics (Bissett $e t$ al., 2005; Boere et al., 2009, 2011; Coolen, 2011; Coolen \& Overmann, 1998, 2007; Coolen et al., 2004, 2006, 2007, 2008, 2009; Corinaldesi et al., 2011; D'Andrea et al., 2006; Epp et al., 2010; Manske et al., 2008; Panieri et al., 2010; Reid et al., 2000; Theroux et al., 2010). Fossil plankton DNA records are particularly useful for identifying past species, most notably phototrophic bacteria and protists, which did not produce or leave diagnostic cellular features in the fossil record or lack diagnostic fossil lipid biomarkers. On the other hand, fossil DNA surveys are subject to several factors that could bias quantitative and qualitative (i.e. species composition) results. Reasons for why species are missed in PCR-based fossil DNA surveys (Coolen et al., 2007) include 
interspecies variability in the level of natural fragmentation of DNA (Boere et al., unpubl.results), interspecies heterogeneity in small subunit rRNA operon copy numbers, and/or PCR primer efficiency and coverage (e.g. Von Wintzingerode et a $l$., 1997; Fogel et al., 1999; Klappenbach et al., 2001; Zhu et al., 2005; LaJeunesse et al., 2005; Potvin \& Lovejoy, 2009).

The majority of the fossil DNA studies focused on the relatively recent past (Holocene), with the exception of the recovery of genuine past photic zone-dwelling cyanobacteria from Mediterranean evaporites, which were deposited during the late Miocene (Messinian) Salinity Crisis $\sim 5.9 \mathrm{Ma}$ ago (Panieri et al., 2010). In addition, $\sim 400$-bp-long 165 rDNA fragments of ancient chemocline bacteria (i.e. obligate anoxygenic photolithoautotrophic green sulfur bacteria) were recovered from up to 217-kyr-old eastern Mediterranean sapropels (Coolen \& Overmann, 2007).

However, studies showing the potential for preservation of fossil DNA from eukaryotic plankton members, which thrived in the pelagic ecosystem at geological time scales beyond the Holocene, are lacking. Eukaryotic 185 rDNA was detected in up to 1-Ma-old deep subsurface sediments of the Peru Margin, but whether this DNA was stemming from pelagic taxa remains unclear because the recovered $18 \mathrm{~S}$ rDNA was not sequenced (Schippers \& Neretin, 2006).

The upper few meters of eastern Mediterranean sediments offer a unique opportunity to study the Pleistocene pelagic eukaryote composition from DNA that has been exposed to varying (post)depositional conditions. These sediments contain organic carbon $\left(\mathrm{C}_{\mathrm{org}}\right)$-rich sediment intervals (sapropels), which were formed as a result of orbitally forced changes in climatic and hydrological conditions leading to increased primary production, development of water column anoxia, and increased preservation of $\mathrm{C}_{\text {org }}$ in the anoxic bottom waters (Cramp \& O'Sullivan, 1999; de Lange et al., 2008; Emeis et al., 2003; Negri et al., 2009; Rohling, 1994) including the preservation of labile compounds such as DNA (Boere $e t a l$., 2011 ; Coolen \& Overmann, 2007). The sapropels are embedded in fully oxidized $\mathrm{C}_{\text {org }}$-lean marls, which were formed after bottom water reventilation reestablished in the eastern Mediterranean Sea and presumably provided less optimal conditions for the preservation of DNA (Boere et al., 2011).

Recently, we performed a comparative multiproxy survey (fossil DNA, calcareous nannofossils, and lipid biomarkers) to test whether preserved genetic signatures provide an accurate view of haptophyte and dinoflagellate populations during deposition of the Holocene Eastern Mediterranean sapropel S1 (Boere et al., 2011). 18S rDNA of dinoflagellates and haptophytes could be recovered from the $\mathrm{C}_{\text {org }}$-rich $S 1$, but the most abundant phylotypes represented species that were not part of the calcareous nannofossil assemblage (Boere et al., 2011) or dinocyst composition (Zonneveld et al., 2001 ). Perhaps the most plausible reason for this discrepancy is the recent understanding that the majority of DNA in marine sediments is extracellular and no longer associated with living or intact cells (Dell'Anno \& Danovaro, 2005), and that this pool of DNA was preserved despite the presence of microbial nucleases (Corinaldesi et al., 2008, 2011). Extracellular DNA in marine sediments can be protected from degradation into small fragments by microbial nucleases for substantial periods when it is adsorbed to mineral and organic matrices (e.g. Lorenz \& Wackernagel, 1987; Pietramellara et al., 2009; Romanowski et al., 1991). More specifically, recent DNA adsorption kinetics experiments revealed that circular prokaryotic DNA is more effectively adsorbed to clay minerals than eukaryotic linear DNA (Nguyen \& Elimelech, 2007; Poly et al., 2000). Therefore, the earlier findings that prokaryotic DNA can be preserved in sediment records older than the Holocene might not necessarily be true for DNA of eukaryotic plankton members.

Using the same core as analyzed by Boere et al. (2011), we extended the stratigraphic survey of ancient dinoflagellates and haptophyte algae and their relative abundance based on preserved partial $18 \mathrm{~S}$ rDNA fragments in Pleistocene eastern Mediterranean sapropels [i.e. S3 ( 30 ka), S4 (105 ka), and $S 5(125 \mathrm{ka})]$ and their intercalating oxidized marls. Because many lipid biomarkers are generally thought to be more recalcitrant than DNA, we performed a parallel quantitative survey of preserved dinosterol and long-chain alkenones as an independent measure for the amount of biomass derived from respectively dinoflagellates and haptophytes of the order Isochrysidales (e.g. Marlowe et al., 1984; Volkman, 2003). Because the location of the studied core was relatively close to the outlet of the Nile, we also determined the Branched and Isoprenoid Tetraethers (BI'T) index (Hopmans et al., 2004) as a measure for the relative amount of terrestrial (fluvial) vs. marine sources of organic matter (OM) including DNA. To our knowledge, this is the first study in which Pleistocene eukaryotic plankton members are both quantified and identified based on preserved genetic signatures, and in which the presence of their fossil DNA is validated via the parallel independent analysis of geochemical proxies.

\section{EXPERIMENTAL}

\section{Setting and sampling}

During the 2004 MIMES cruise on the R $\checkmark$ Pelagia as part of the MEDIFLUX project, a piston core (MS66PC) was recovered from near the deep-sea Nile fan, Eastern Mediterranean (location: 33N1.9' 31E47.9') at a water depth of $1630 \mathrm{~m}$ (Boere et al., 2011; Fig. S1). The total length of the core was $6 \mathrm{~m}$ and included the sediment-water interface. A sediment section located between 137 and $174 \mathrm{~cm}$ was lost during sampling. Visual inspection showed that the core contained sapropels S1, S3, S4, and S5, an observation that was corroborated by $\delta^{18} \mathrm{O}$ measurements on bulk carbonate. 
Inside a closed container on board of the $\mathrm{R} / \mathrm{V}$ Pelagia, the core was split in half and processed using aseptic conditions to avoid cross contamination: The upper one $\mathrm{cm}$ of exposed sediment from the working core half was scraped off using sterilized knives to reveal visibly undisturbed depositional laminations. Samples for DNA and lipid analyses were taken at $1 \mathrm{~cm}$ resolution from the sapropel intervals and at a lower resolution (i.e. $2 \mathrm{~cm}$ intervals every $10-20 \mathrm{~cm}$ ) from the oxidized marls by pressing headless (ends cut) sterile plastic syringes into the sediments. Hereby, the top $1 \mathrm{~cm}$ of the sediment in each syringe was omitted, and a distance of $2 \mathrm{~cm}$ between the core liner and subsampled sediment was maintained while using this syringe sampling method to avoid cross contamination (Coolen et al., 2009). Subsamples were transferred to sterile disposable $50-\mathrm{mL}$ centrifuge tubes and stored frozen $-40{ }^{\circ} \mathrm{C}$ until further analysis. Subsamples at $1 \mathrm{~cm}$ resolution were also obtained for inorganic geochemistry and stored at $4{ }^{\circ} \mathrm{C}$.

\section{DNA extraction}

The extraction of DNA was performed in clean laboratories dedicated for ancient DNA work at the Royal Netherlands Institute for Sea Research (NIOZ) and at the Woods Hole Oceanographic Institution (WHOI). Extensive measures were taken to prevent contamination of samples and reagents used during DNA extraction with foreign DNA as described in detail previously (Boere et al., 2011; Coolen $e t a l$, 2009). At the Royal NIOZ, a total of 28 samples from depths spanning early, mid, and final deposition of sapropels S1 [six samples], S3 [4], S4 [5], and S5 [7] as well as the $\mathrm{C}_{\text {org-lean }}$ sediments between sapropels [6], were selected for fossil DNA and lipid analysis. Per sample depth, approximately 10-20 g wet sediment was available. The entire sample was defrosted, briefly homogenized by vortexing, and 5-10 g wet sediment was used for DNA extraction. The remaining sample fraction was refrozen and used for lipid biomarker analysis.

Fifteen additional samples from this core (S1 [3], S3 [1], S4 [2], S5 [3], and from the intercalating sediment marls [6]) were shipped to the ancient DNA-dedicated laboratory at WHOI for the qualitative and quantitative survey of the eukaryotic $18 \mathrm{~S}$ rDNA pool. This served as an additional, independent validation of the data obtained at the NIOZ and to check for possible laboratory-specific contaminations.

Total DNA was extracted using the PowerMax ${ }^{\mathrm{TM}}$ Soil DNA isolation kit (MoBio laboratories, Carlsbad, CA, USA), according to the manufacturer's guidelines. The resulting DNA was concentrated with a cold ethanol precipitation, redissolved in $100 \mu \mathrm{L} 1 \times$ sterile Tris-EDTA buffer (Ambion) and frozen at $-80{ }^{\circ} \mathrm{C}$ until further use. The integrity and yield of DNA in the extracts were checked by gel electrophoresis (Fig. S2). Nucleic acid yield was quantified by fluorescence (PicoGreen; MoBiTec, Göttingen, Germany).
At both laboratories, extraction controls (EC) were subjected to the entire extraction procedure, with ultraclean PCR water (Sigma-Aldrich, St Louis, MO, USA) in place of sediment. Aliquots of those samples were subjected to PCR (see below) to monitor for contamination during the DNA extraction.

\section{Quantitative Polymerase Chain Reaction (qPCR)}

The amount of DNA (from eukaryotes in general, haptophytes, and dinoflagellates) in each sediment interval was determined by qPCR and expressed as number of $18 \mathrm{~S}$ rDNA copies per nanogram of extracted DNA to normalize for possible variations in DNA extraction efficiencies between samples. All qPCRs were run on an iCycler $\mathrm{IQ}^{\mathrm{TM}}$ real-time PCR detection system (Bio-Rad, Hercules, CA, USA) at the NIOZ or a Realplex qPCR cycler (Eppendorf, Westbury, NY, USA) at WHOI, using a SYBR Green I (Invitrogen, Carlsbad, CA, USA) assay. Each reaction contained the following reagents and concentrations: $5 \mu \mathrm{L} 1 \times$ Picomaxx buffer and 2.5 units Picomaxx enzyme (Stratagene, LaJolla, CA, USA), $0.25 \mathrm{~mm}$ of each nucleotide, $50 \mu \mathrm{g}$ bovin serum albumin, $1 \mathrm{mM} \mathrm{MgCl}_{2}, 1 \times \mathrm{SYBR}^{\mathrm{E}}$ Green I, $10 \mathrm{~nm}$ fluorescein, and $0.2 \mu \mathrm{M}$ final concentration of each of the primers listed in Table S1, and Ultra Clean PCR water (Sigma-Aldrich) added to $50 \mu \mathrm{L}$. The PCR ingredients used at WHOI differed slightly in that $4.5 \mathrm{mM} \mathrm{MgCl}_{2}, 0.5 \times \mathrm{SYBR}^{\overline{8}}$ Green and no fluorescein were used. Three different primer sets were used for targeting similar sized (400-500 bp long) 18S rDNA fragments of general eukaryotes, haptophytes, and dinoflagellates, respectively (Table $S 1$ ).

All PCR programs contained an initial denaturing step at $96{ }^{\circ} \mathrm{C}$ for $4 \mathrm{~min}$, followed by 32 or 40 cycles of denaturing $\left(94{ }^{\circ} \mathrm{C}, 40 \mathrm{~s}\right), 40 \mathrm{~s}$ of annealing at varying temperatures (Table S1), elongation $\left(72{ }^{\circ} \mathrm{C}, 60 \mathrm{~s}\right)$, and imaging of newly formed SYBR ${ }^{6}$ Green-stained dsDNA $\left(80^{\circ} \mathrm{C}, 20 \mathrm{~s}\right)$. A final elongation step $\left(72^{\circ} \mathrm{C}, 10 \mathrm{~min}\right.$ ) was added for the quantification reaction. All reactions were stopped within the exponential phase that was achieved after 32 or after 40 cycles depending on the amount of initial template in each sample. Amplification was followed by a melting curve analysis, in which fluorescence in each sample was measured during a stepwise increase of the temperature from $60^{\circ} \mathrm{C}$ to $96^{\circ} \mathrm{C}$ in $0.5^{\circ} \mathrm{C}$ temperature increments. Between $10^{\circ}$ and $10^{7}$ copies of full-length $18 \mathrm{~S}$ rDNA of Emiliania huxleyi was used as a standard series to quantify the number of general eukaryote $18 \mathrm{~S} \mathrm{rDNA}$ and haptophyte $18 \mathrm{~S} \mathrm{rDNA}$ copies in our samples. A standard series from $10^{0}$ to $10^{7}$ copies of full-length rDNA of Scrippsiella sp. served to quantify the fossil dinoflagellate 18 S rDNA. PCR efficiencies were found to be $>92 \%$, and the quality and length of the produced PCR amplicons was checked by standard agarose gel electrophoresis.

Prior to these qPCR assays, each DNA extract was checked for the presence of PCR-inhibiting impurities, which would 
otherwise have lowered the efficiency and accuracy of the qPCRs (e.g. Coolen et al., 2009). For this, 50- $\mu$ L PCRs were assayed with $1 \mu \mathrm{L}$ of sample DNA plus $10^{6}$ copies of fulllength E. coli $16 \mathrm{~S}$ rDNA and general bacterial primers. The addition of $E$. coli $16 S \mathrm{rDNA}$ was performed in a separate general-use laboratory because PCR products with high copy number template DNA are not allowed in both ancient DNA laboratories. The threshold cycles of each reaction with DNA of an individual sample were then compared to a control reaction that only contained $E$. coli $16 \mathrm{~S}$ rDNA. This assay revealed slightly delayed threshold cycles indicative of minor inhibition for some samples. In these cases, PCR inhibition could be completely eliminated by using 5-10 times diluted template DNA in the qPCR assays (Coolen et al., 2009).

\section{Denaturing gradient gel electrophoresis (DGGE) and sequencing of bands}

To generate template for subsequent DGGE analysis of the samples analyzed at the NIOZ, $1 \mu \mathrm{L}$ of the qPCRs from the samples and controls served as template for a second round of PCR (two-step PCR approach) with 15 amplification cycles and fresh PCR reagents $(20 \mu \mathrm{L}$ reaction mixtures). These reactions contained the same forward primers, but with modified reverse primers to which a GC-clamp, i.e. a 40-bp-long GC-rich tag was attached (called 'GC-primer' from now on). The addition of a GC-clamp prevents complete dissociation of the two strands and loss of amplicons during DGGE analysis (Muyzer et al., 1993).

This two-step approach served also as a test for the specificity of the qPCRs because the DGGE bands generated during the second round of PCR were subsequently sequenced. In addition, all field samples and controls analyzed at the NIOZ were directly amplified with GC primers (i.e. one-step PCR approach) with a total of 42 amplification cycles, and the diversity of the sequenced DGGE bands was compared with the results obtained via the two-step PCR approach. The direct use of GC primers generally results in reduced PCR efficiencies ( $85 \%$ or less) and was therefore avoided for $\mathrm{qPCR}$ purposes. The samples analyzed at WHOI were only analyzed using this one-step PCR approach. For the PCRs with GC primers, the final extension step was prolonged to $30 \mathrm{~min}$ following Janse et al. (2004).

After checking the quality of PCR products on agarose gel, $\sim 100 \mathrm{ng}$ DNA of each reaction was run on DGGE. The polyacrylamide gels $(6 \%, \mathrm{wt} / \mathrm{vol})$ contained a denaturing gradient of $20-50 \%$ (where $100 \%$ denaturing reagent equals $7 \mathrm{M}$ urea and $40 \%$ formamide) for eukaryotes and haptophytes. For dinoflagellates, a gradient of $20-60 \%$ was used. Gels were run for $5 \mathrm{~h}$ at $200 \mathrm{~V}\left(12.5 \mathrm{~V} \mathrm{~cm}^{-1}\right)$ in $1 \times$ TAE buffer at a temperature of $60^{\circ} \mathrm{C}$. Subsequently, the gel was stained for $30 \mathrm{~min}$ with $1 \times$ SYBR Gold (Molecular Probes, Eugene, OR, USA), rinsed with Milli-Q, and visualized using a Dark Reader (Clare Chemical Research Inc., Dolores, CO, USA). Bands melting at unique positions in the gel were excised using flame-sterilized scalpels, and the DNA in each band was eluted in $50 \mu \mathrm{L}$ $\mathrm{l} \times$ TE-buffer for $24 \mathrm{~h}$. In addition, bands that melted at identical vertical positions in the gel were analyzed to assess intra-band sequence diversity. Subsequently, the bands were re-amplified using the original primer set and purified using the Genscript QuickClean PCR purification kit (Genscript, Piscataway, NJ, USA). Purified PCR products were sent to Macrogen Inc. (Seoul, Korea) for standard Sanger sequencing.

\section{Phylogenetic analyses}

The phylogenetic affinity of recovered sequences was initially identified by BLAST searches using the NCBI website (http://www.ncbi.nlm.nih.gov/). Sequences were subsequently imported into the SILVA database (SSURef 93; (Pruesse et al., 2007) using the ARB software package (version December 2007; Ludwig et al., 2004)). The sequences were aligned to the SILVA SSU reference alignment using the FastAligner tool in ARB. The alignment was checked and refined manually, and sequenced DGGE bands were grouped into operational taxonomic units or phylotypes based on $98 \%$ sequence similarity cutoff value using the program DOTUR (Schloss \& Handelsman, 2005). Phylogenetic analyses included distance matrix and maximum likelihood approaches applying several position variability filters. Finally, a Bayesian phylogenetic inference analysis was performed on all recovered haptophyte and dinoflagellate phylotypes and on closely related relatives. This analysis was performed in the program MrBAYES (version 3.1.2, http://mrbayes.csit.fsu.edu) using two metropolis-coupled Markov chains, each comprising four chains, which were run for 1000000 generations. Trees were sampled every 1000th generation. The first 100 trees $(10 \%)$ were discarded as burn-in, and the remaining 900 trees were assembled into a consensus tree.

Sequences recovered at Royal NIOZ with general euk aryote primers are deposited in NCBI under accession numbers FJ785836-FJ785859 (archaea), FJ785860-FJ785896 (fungi), and FJ785897-FJ785984 (remaining part of sequences obtained by the general eukaryotic assay). The haptophyte- and dinoflagellate-specific sequences are deposited under accession numbers: FJ796994-FJ797011 and FJ797012-FJ797032, respectively. Sequences obtained by the general eukaryotic assay at WHOI were deposited under accession numbers FJ834307-FJ834324.

\section{Total organic carbon, elemental composition, and lipid geochemistry}

The inorganic bulk elemental composition was analyzed from freeze-dried sediment by inductively coupled plasma-atomic emission spectrometry (ICP-AES) after the three-step digestion to ensure total dissolution as described previously 
(Reitz et al., 2006). Organic carbon and $\mathrm{CaCO}_{3}$ contents were measured on a Fisons Instruments CNS NA analyzer using dry combustion at $1030^{\circ} \mathrm{C}$ (Reitz et al., 2006).

Parallel lipid analyses were performed on the samples that were analyzed for fossil DNA at the Royal NIOZ. Sediments $(\sim 10 \mathrm{~g})$ were freeze-dried and ultrasonically extracted five times with dichloromethane/methanol (DCM/MeOH; 2:1, $\mathrm{v} / \mathrm{v}$ ). The solvent was removed by rotary evaporation under vacuum. The extracts were methylated with diazomethane and separated by column chromatography on $\mathrm{Al}_{2} \mathrm{O}_{3}$ into apolar (containing alkenones) and polar fractions using respectively $\mathrm{DCM}$ and $\mathrm{DCM} / \mathrm{MeOH}(1: 1, \mathrm{v} / \mathrm{v})$ as eluents. An internal standard (6,6-d2-3-methyl-eicosane) was added to the apolar fractions prior to gas chromatography (GC) and gas chromatography-mass spectrometry (GC/MS) analyses. The same internal standard (6,6-d2-3-methyl-eicosane) was added to half of the polar fraction, and this total lipid fraction was subsequently silylated with bis(trimethyl)trifluoracetamide at $60^{\circ} \mathrm{C}$ for $20 \mathrm{~min}$ and analyzed by GC and GC/MS.

To quantify the biomarker concentrations, GC analyses were performed using a Hewlett-Packard 5890 instrument equipped with a flame ionization detector and an on-column injector. A fused silica capillary column $(25 \mathrm{~m} \times 0.32 \mathrm{~mm}$ i.d.) coated with CP-Sil 5 (film thickness $0.12 \mu \mathrm{m}$ ) was used with helium as carrier gas. The oven was programmed at a starting (injection) temperature of $70^{\circ} \mathrm{C}$ and programmed to $130^{\circ} \mathrm{C}$ at $20^{\circ} \mathrm{C} / \mathrm{min}$ and then to $320^{\circ} \mathrm{C}$ at $4{ }^{\circ} \mathrm{C} / \mathrm{min}$, at which it remained for $10 \mathrm{~min}$. The different fractions were analyzed by GC/MS using a Finnigan Trace GC Ultra coupled to a Finnigan Trace DSQ mass spectrometer. GC conditions and column were as described above. The column was directly inserted into the electron impact ion source of the DSQ quadrupole mass spectrometer, scanning a mass range of $\mathrm{m} / \mathrm{z} 50-800$ at three scans per second and an ionization energy of $70 \mathrm{eV}$.

The Branched and Isoprenoid Tetraether (BIT) index was measured by dissolving the other half of the polar fractions in hexane/n-propanol $(99: 1, \mathrm{v} / \mathrm{v})$ to a concentration of $2 \mathrm{mg} \mathrm{mL} \mathrm{m}^{-1}$ and filtering over a $0.45-\mu \mathrm{m}, 4$-mm-diameter PTFE filter. This was analyzed using high-performance liquid chromatography/atmospheric pressure positive ion chemical ionization mass spectrometry (HPLC/APCI-MS) as described by Hopmans et al. (2004).

\section{RESULTS}

\section{Elemental composition, sedimentary organic carbon, and DNA content}

The location of the sapropels in the core was determined based on the organic carbon $\left(\mathrm{C}_{\text {org }}\right)$ content and the ratio between the elements barium and aluminum ( $\mathrm{Ba} / \mathrm{Al}$ ratio) (Fig. 1A). The $\mathrm{C}_{\text {org }}$ content was highest (4\%) in the deepest sapropel $S 5$, and $\sim 2 \mathrm{wt} \%$ in sapropels $\mathrm{S} 1, \mathrm{S3}$, and $\mathrm{S} 4$. $\mathrm{C}_{\text {org }}$ was
$<0.4 \mathrm{wt} \%$ in the intercalating marls (Fig. $1 \mathrm{~A}$ ). The $\mathrm{Ba} / \mathrm{Al}$ ratio was most elevated in the S5 (ca. 200) and in the younger sapropels (ca. 100-150), with values of $\sim 30-40$ in the intercalating marls (Fig. 1A). A few $\mathrm{cm}$ above the $\mathrm{C}_{\text {org }}$-rich sapropels $S 3$, and especially above $S 1$, the $\mathrm{Ba} / \mathrm{Al}$ ratio remains high, which is indicative of postdepositional reoxidation of the upper few $\mathrm{cm}$ of these sapropels (de Lange $e$ t al., 2008). Postdepositional re-oxidation was not apparent for S4 and S5 sapropels, but a temporary decrease in $\mathrm{C}_{\text {org }}$ content and $\mathrm{Ba} / \mathrm{Al}$ ratio can be observed during mid $\$ 4$ and $\$ 5$ deposition, which has been interpreted as an interruption of sapropel deposition (de Rijk et al., 1999).

DNA concentrations were highest in the $S 1$ interval $\left(8-40 \mu \mathrm{g} \mathrm{g}^{-1} \mathrm{C}_{\text {org }}\right)$ and between 0.5 and $8 \mu \mathrm{g} \mathrm{g}^{-1} \mathrm{C}_{\text {org }}$ in the Pleistocene sapropels. DNA concentrations were generally below the detection limit with the picogreen method $\left(<0.1 \mu \mathrm{g} \mathrm{g}^{-1} \mathrm{C}_{\mathrm{org}}\right)$ in the majority of the analyzed intercalating marls with the exception of one layer at $\sim 100 \mathrm{~cm}$ (between the $S 1$ and $S 3$ ) and at $\sim 500 \mathrm{~cm}$ (between the $S 4 b$ and S5) (Fig. 1D). Agarose gel electrophoresis revealed that the majority of the bulk sediment DNA was of high molecular weight even in the oldest sapropels with a smear of fragmented DNA down to 200 bp or less, whereas the intercalating marls and extraction control did not yield visible amounts of DNA on the gel (Fig. S2).

\section{Quantitative analysis of eukaryotic DNA in the Holocene to late-Pleistocene sediments}

Eukaryotic $18 \mathrm{~S}$ rDNA was quantified throughout the Pleistocene eastern Mediterranean sediments by qPCR with a general eukaryote primer set without GC-clamp (Table S1). All samples were analyzed in duplicate and yielded reproducible results. The abundance of eukaryotic 185 rDNA was highest in all four sapropels and varied only up to one order of magnitude between the analyzed intervals $\left(5 \times 10^{6}\right.$ $3 \times 10^{7}$ copies $\mu \mathrm{g}^{-1}$ ) (Fig. 1E). Similar amounts of eukaryotic $18 \mathrm{~S}$ rDNA were measured in the two samples from the intercalating marl between $\mathrm{S} 1$ and S3, whereas eukaryotic $18 \mathrm{~S}$ rDNA copy numbers were 1-2 orders of magnitude lower in intercalating marls just above or below the $\$ 4$ and S5 (Fig. 1E).

In addition, we specifically quantified the amount of preserved partial $18 \mathrm{~S}$ rDNA of dinoflagellates and haptophyte algae throughout the late-Pleistocene sediment record (Fig. 1F,G). Dinoflagellate $18 \mathrm{~S}$ rDNA comprised $\sim 10 \%$ of the total eukaryote $18 \mathrm{~S} \mathrm{rDNA}$ (maximum $8 \times 10^{5}$ copies $\mu \mathrm{g}^{-1}$ extracted DNA) in the S1 with 20 -fold lower concentration just below the SI (Fig. IF). In the Pleistocene intervals, correctly sized dinoflagellate $18 \mathrm{~S}$ rDNA amplicons were only found in two horizons: in sapropel $\mathrm{S} 3$ at $378 \mathrm{cmbsf}$ and in sapropel S5 at $530 \mathrm{cmbsf}$ at concentrations up to two orders of magnitude lower than in the S1 (Fig. 1F). The dinoflagellate $18 \mathrm{~S} \mathrm{rDNA}$ content in the $\mathrm{S} 3$ at $378 \mathrm{~cm}$ was just above 


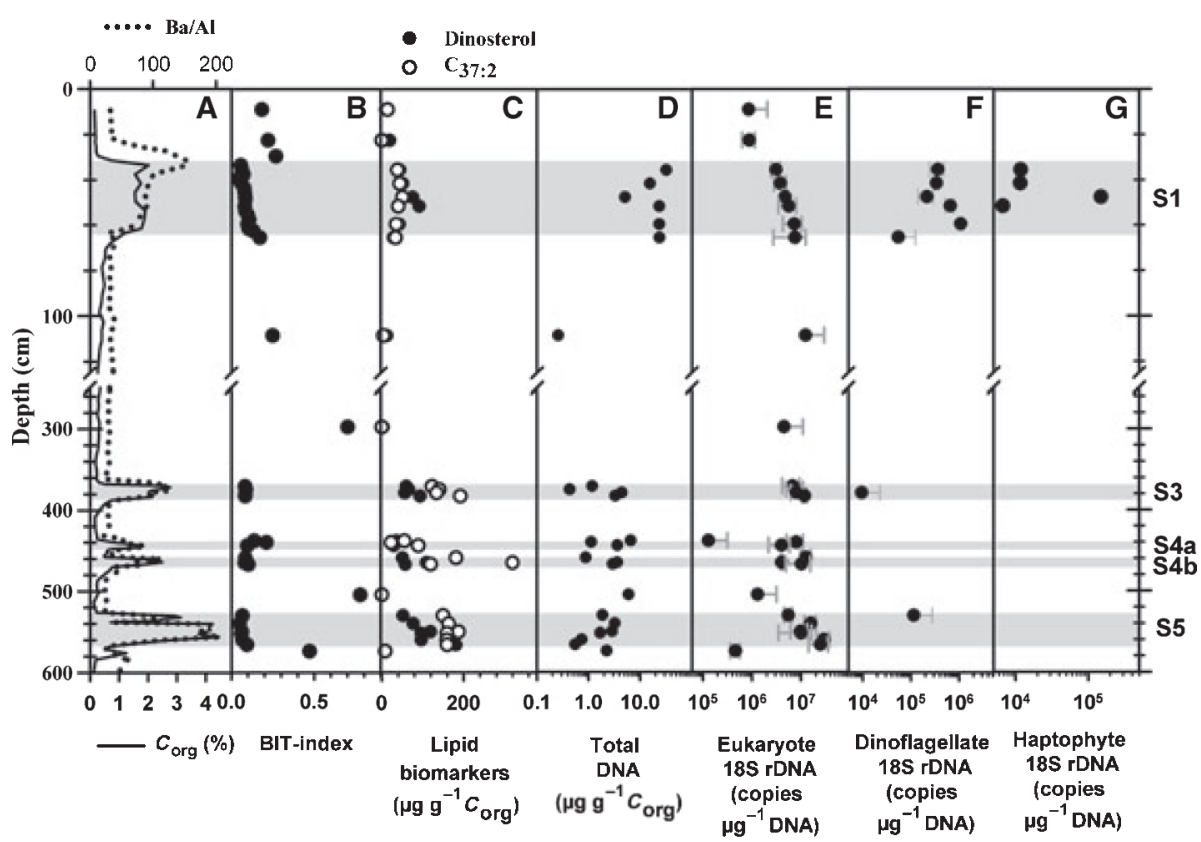

Fig. 1 Geochemical, lipid biomarker, and DNA profiles of the investigated core (MS66PC). Gray-shaded areas mark the vertical positions of the four sapropels ( 11 , S3, S4a+b, and S5). (A) Organic carbon content $\left(\mathrm{C}_{\text {org }} ; w \mathrm{~W} \%\right.$ ) and $\mathrm{Ba} / \mathrm{Al}$ ratio. The core was analyzed at $1-\mathrm{cm}$ interval resolution for these parameters. (B) Branched and Isoprenoid Tetraethers (BIT) index. The same samples that were analyzed for lipids and DNA were used for the BIT index, except for sapropel 51 , which was analyzed at higher resolution. (C) Concentrations of selected lipid biomarkers for dinoflagellates (dinosterol) vs. haptophytes ( $C_{37: 2}$ methyl ketone). (D) Total extracted DNA concentration in microgram per gram organic carbon. ( $E, F, G$ ) $18 S$ rDNA copy numbers as revealed by $q P C R$ with (E) general eukaryotic primers Euk1f/Euk516R, (F) a dinoflagellate-specific primer set Euk1f/DinoRev, and (G) a haptophyte-specific primer set Prym448/Prym884. The $q$ PCR data were expressed as copy numbers per microgram extracted DNA to normalize for possible variations in the DNA extraction efficiencies between samples. Error bars represent the standard deviation of two replicates. The break in the depth axis represents the sediment interval $125-250 \mathrm{~cm}$ below sea floor.

the detection limit $\left(\sim 5 \times 10^{3}\right.$ copies $\mu g^{-1}$ extracted DNA). QPCR using haptophyte-specific primers revealed that $\sim 400$ bp-long haptophyte $18 \mathrm{~S}$ rDNA fragments represented $1 \%$ or less (up to $2 \times 10^{5}$ copies $\mu \mathrm{g}^{-1}$ extracted DNA) of the total number of eukaryotic $18 S$ rDNA copies in the $\mathbf{1}$ (Fig. 1G). These quantitative results were not reproducible, suggesting that these values were close to the detection limit. Despite the low copy numbers, reamplification of the qPCR with GC primers for DGGE and subsequent phylogenetic analysis of sequenced DGGE bands yielded unambiguous haptophyte sequences as outlined below. Haptophyte DNA was below the detection limit $<10^{3}$ copies $\mu \mathrm{g}^{-1}$ extracted DNA in the Pleistocene sediments.

\section{Eukaryotic phylotypes recovered from the Holocene to late-Pleistocene sediments}

The amplicons from the $\mathrm{qPCR}$ assays were reamplified with GC primers (Table $S 1$ ) and subjected to DGGE. Excised DGGE bands were subsequently sequenced for phylogenetic analysis. The recovered phylotypes were, where possible, clustered at higher taxonomic levels, and the number of phylotypes per higher level was determined per sediment interval (either sapropel or intercalating sediment interval). Table 1 provides an overview of the distribution of these higher taxonomic groups per depth interval. The closest BLAST hits, including accession number and sequence similarity (\%), of recovered phylotypes are shown in the more detailed overview Table 2. Bands melting at identical positions in the gel were shown to contain identical sequences and therefore no intraband sequence diversity.

The majority of eukaryotic phylotypes in the $\$ 1$ represented marine protists of which Alveolata (a superphylum comprising dinoflagellates, ciliates, apicomplexa, and 'unclassified alveolata') represented the largest group. Other protists included cercozoa, chlorophytes (green algae) related to Nannochloris, and a stramenopile belonging to the MAST-12 cluster (cf. clone DSGM-40 (Takishita et al., 2005, 2007); Table 1). One phylotypes ('unknown affiliation', Table 1 ) is related to the uncultured marine clone CCI73 (AY179972), which was isolated from an anoxic water-sediment interface and is cur rently without known close relatives (Stoeck \& Epstein, 2003).

Besides protist DNA, metazoan phylotypes were found in sapropel S1, most notably zooplankton (copepods; Euk-22 and Euk-26) and a phylotype related to acorn worms (Enteropneusta; Euk-17) (Table 2). Two additional phylotypes recovered from sapropel $\$ 1$ were related to marine fungi. One of these (cf. Pichia guilliermondii; FUNG-1) was found throughout the core (outlined below), whereas a fungal phyl- 
Table 1 Number of specific eukaryote phylotypes in the various sections of the investigated core

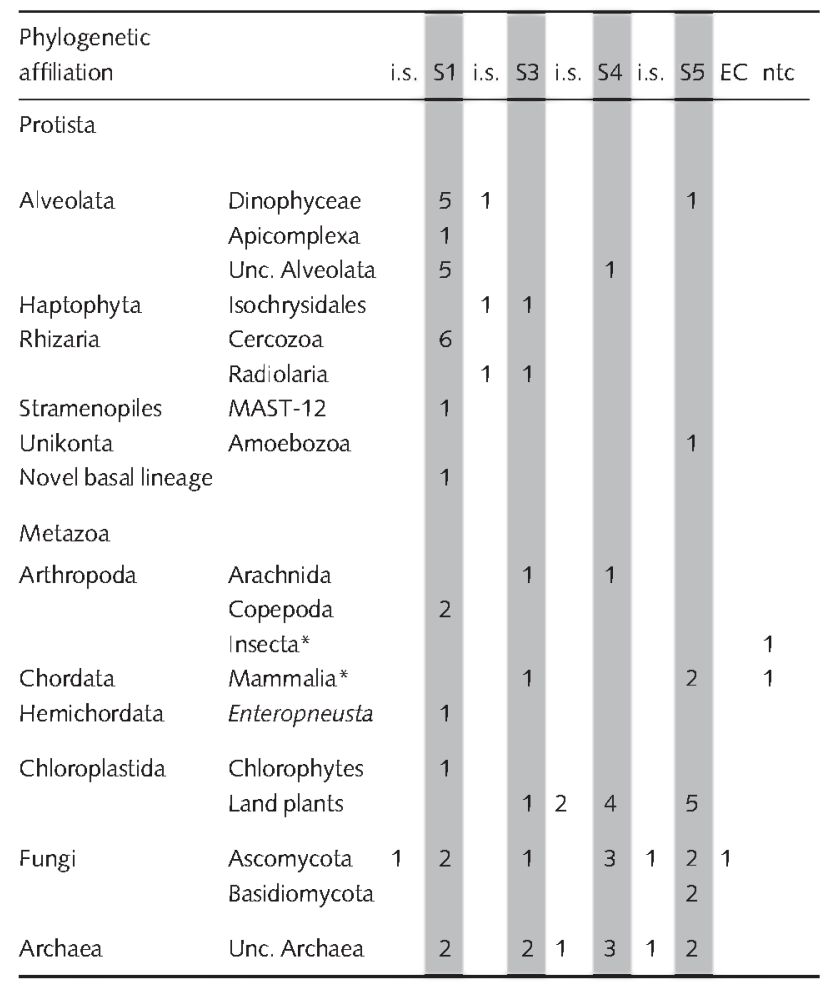

The first column shows higher taxonomic grouping nomenclature. The number of phylotypes found per higher taxonomic group is shown for each sediment interval. Sapropel layers are shown in shaded columns. Phylotypes that were found in nontemplate controls are marked with an asterisk $\left({ }^{*}\right)$.

Unc., uncultured; Sap, sapropel; i.s., Nonsapropelic intercalating sediment; e.c., extraction control; ntc, nontemplate control. Compare Table 2 for more detailed phylogenetic information.

otype (FUNG-4) related to Metschnikowia sp. (Ascomycetes) was found only in S1.

Preserved partial 185 rDNA of marine protists could only occasionally be recovered from the Pleistocene sediments: Two phylotypes (EUK-24 and EUK-42) distantly related to named dinoflagellate species (Fig. 2A) were recovered from the intercalating marl between $S 1$ and $S 3$ as well as from $S 5$, but not from S1 (Table 2). S4 harbored a single sequence (Euk-32) related to uncultured alveolates from the photic zone of the Sargasso Sea (AY664058; Fig. 2A, Tables 1 and 2) (Armbrust et al., 2008). A sequence (Euk-23) with $99 \%$ sequence similarity to the alkenone-producing coccolithophorid E. buxleyi (Fig. 2B) was recovered from the intercalating marl between $S 1$ and S3 as well as in S3 (Tables 1 and 2). The latter sediments also revealed two sequences related to siliceous nannoplanktonic radiolarian species (Euk-13 and Euk-20; Tables 1 and 2). Furthermore, the S5 contained DNA of an unassigned amoebozoan (EUK-25).

In contrast, marine fungi, in particular $P$.guilliermondii (Table 1), were consistently present throughout the core below S1. Marine fungi related to Rhodosporidium and
Rhodotorula were only found in sapropel S5 (FUNG-2 and FUNG-7). S4 contained fungal sequences related to uncultured Trichocomaceae (FUNG-5) and Acremonium (FUNG-6) (Table 2). Besides marine fungi, the numerically most abundant phylotypes (13 phylotypes) that were recovered from below the sapropel S1 were related to a wide variety of land plants (Table 2).

\section{Controls for monitoring contaminations during sampling and handling}

To monitor possible contamination of the samples with foreign DNA, a set of blanks and controls were processed in parallel to the samples. Extraction controls (ECs) were subjected to the same DNA extraction protocol as the samples were, but the sediment replaced with PCR water. In addition, during PCR preparation, nontemplate controls (NTCs) containing all PCR ingredients except template DNA were run alongside the samples. To check for laboratory-specific contamination, another selection of 15 pristine samples was independently extracted and analyzed at the WHOI laboratory using a similar qPCR-DGGE-sequencing approach.

The ECs that were subject to the two-step PCR approach at the NIOZ revealed the presence of archaeal $16 \mathrm{SDNA}$ (ARCH-3), whereas insect and human DNA were occasionally recovered from the NTCs (Table 2). The archaeal and human sequences were also recovered from some of the investigated sediment samples and regarded as contamination. In addition, one of the extraction controls yielded the fungal phylotype related to $P$. guilliermondii which was also recovered from the sedimentary DNA extracts. Because this same fungal sequence was never found in the NTCs, the EC was likely contaminated with a sample during the extraction procedure.

The parallel analysis at WHOI with a different set of samples of S1-S5 and intercalating sediment intervals from core MS66PC revealed a comparable pattern in preserved eukaryotic DNA with sometimes $100 \%$ sequence similarity to phylotypes found in the samples analyzed at the NIOZ. The one-step PCR assay with general eukaryotic primers yielded 14 phylotypes. Five of these phylotypes were related to marine protists and were related or identical to sequences found at the Royal NIOZ (Table 2). The phylotypes from sediments analyzed at WHOI older than the SI contained the same fungal phylotype ( $P$. guilliermondii) found in the sediments analyzed at Royal NIOZ, or sequences from land plants. $P$.guilliermondii was the only sequence recovered from the intercalating $\mathrm{C}_{\text {org }}$-poor marls, and nonspecific amplification of archaeal $16 \mathrm{~S}$ rDNA was not apparent from the one-step PCR approach directly with GC primers at WHOI (Table 2). The ECs analyzed during the one-step PCR approach at WHOI remained negative, but one of the NTCs showed a Picea-related plant sequence (Table 2). For reasons discussed below, phylotype Euk-12 with identical sequence to Zea 
Table 2 Phylogenetic affinity of recovered phylotypes using general eukaryote primers

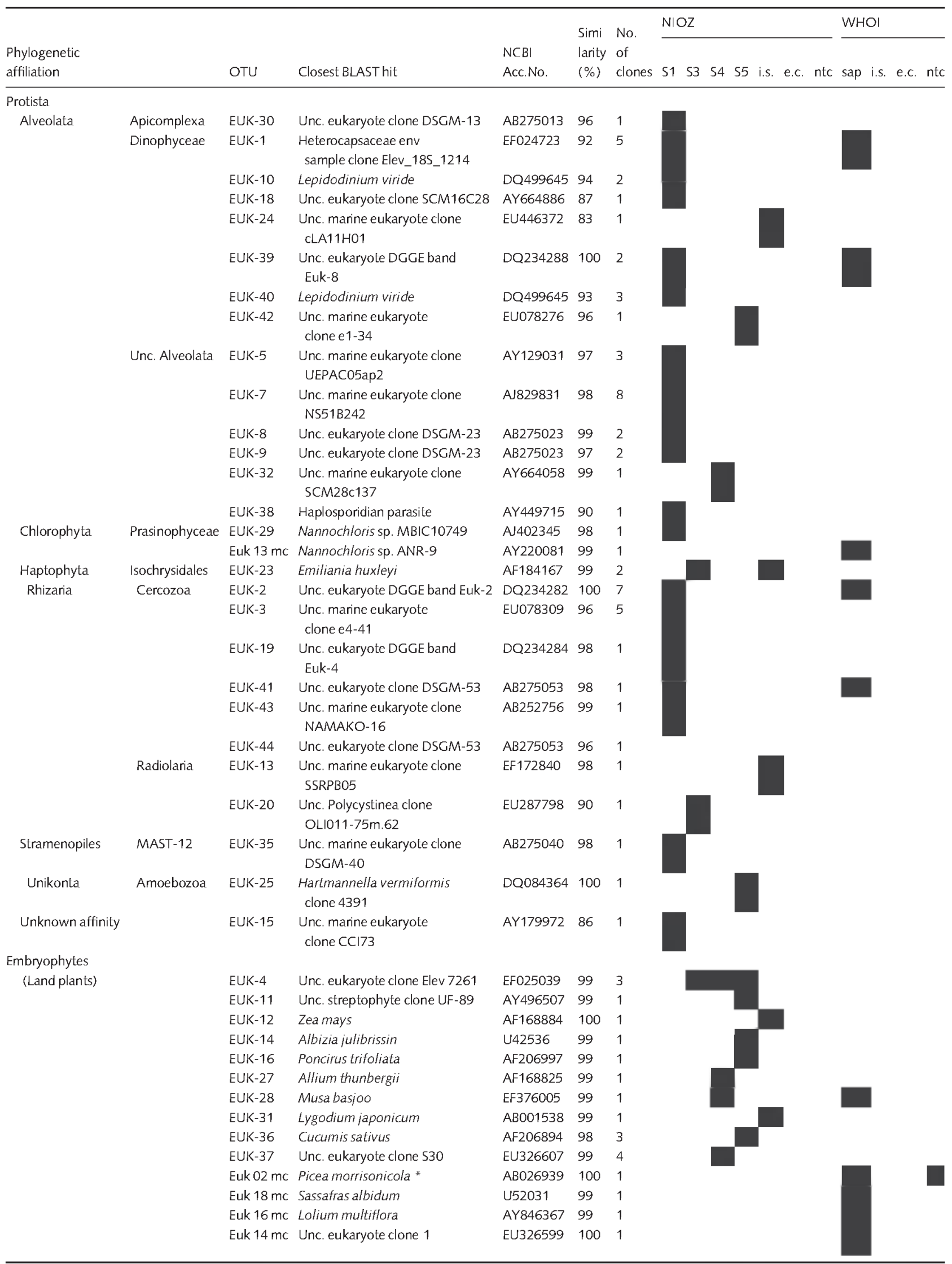


Table 2 (Continued)

\begin{tabular}{|c|c|c|c|c|c|c|c|c|c|c|c|c|c|c|c|}
\hline \multirow{2}{*}{$\begin{array}{l}\text { Phylogenetic } \\
\text { affiliation }\end{array}$} & & \multirow[b]{2}{*}{ OTU } & \multirow[b]{2}{*}{ Closest BLAST hit } & \multirow{2}{*}{$\begin{array}{l}\text { NCBI } \\
\text { Acc.No. }\end{array}$} & \multirow{2}{*}{$\begin{array}{l}\text { Simi } \\
\text { larity } \\
(\%)\end{array}$} & \multirow{2}{*}{$\begin{array}{l}\text { No. } \\
\text { of } \\
\text { clones }\end{array}$} & \multicolumn{6}{|l|}{$\mathrm{NIOZ}$} & \multicolumn{3}{|c|}{ WHOl } \\
\hline & & & & & & & $51 \quad 53$ & 54 & $\$ 5$ & i.s. & e.c. & ntc & sap & i.s. & e.c. ntc \\
\hline \multicolumn{16}{|l|}{ Metazoa } \\
\hline \multirow[t]{6}{*}{ Arthropoda } & Arachnida & EUK-34 & Sitticus palustris & DQ665749 & 97 & 1 & & & & & & & & & \\
\hline & & EUK-21 & Schwiebea pseudotsuqae & EU152499 & 97 & 1 & & & & & & & & & \\
\hline & Copepoda & EUK-22 & Drepanopus forcipatus & AF462321 & 99 & 1 & & & & & & & & & \\
\hline & & EUK-26 & Haloptilus ocellatus & AY118069 & 96 & 2 & & & & & & & & & \\
\hline & Insecta & EUK-33 & Discoderus cordicollis* & AF012472 & 98 & 1 & & & & & & & & & \\
\hline & & Euk $07 \mathrm{mc}$ & Laphystia tolandi & $E F 650144$ & 95 & 1 & & & & & & & & & \\
\hline Chordata & Mammalia & EUK-6 & Homo sapiens* & EU647001 & 99 & 6 & & & & & & & & & \\
\hline Hemichordata & Enteropneusta & EUK-17 & Saccoglossus pusillus & AF236800 & 90 & 1 & & & & & & & & & \\
\hline \multicolumn{16}{|l|}{ Fungi } \\
\hline \multirow[t]{5}{*}{ Ascomycota } & & FUNG-1 & Pichia guilliermondii & EU784644 & 99 & 29 & & & & & & & & & \\
\hline & & FUNG-3 & Lewia infectoria & U43465 & 99 & 2 & & & & & & & & & \\
\hline & & FUNG-4 & Metschnikowia & AB023475 & 95 & 1 & & & & & & & & & \\
\hline & & FUNG-5 & $\begin{array}{l}\text { Unc. Trichocomaceae } \\
\text { clone } 8-2-5\end{array}$ & EU085016 & 99 & 1 & & & & & & & & & \\
\hline & & FUNG-6 & Acremonium sp CSSF-1 & AB167384 & 99 & 1 & & & & & & & & & \\
\hline \multirow[t]{2}{*}{ Basidiomycota } & & FUNG-2 & Rhodosporidium azoricum & $\mathrm{AB} 073269$ & 99 & 3 & & & & & & & & & \\
\hline & & FUNG-7 & Rhodotorula marina & AB126645 & 99 & 1 & & & & & & & & & \\
\hline \multicolumn{16}{|l|}{ Archaea } \\
\hline & & $\mathrm{ARCH}-1$ & Unc archaeon clone 280 NJ33E & AM072592 & 87 & 9 & & & & & & & & & \\
\hline & & $\mathrm{ARCH}-2$ & $\begin{array}{l}\text { Unc euryarchaeote } \\
\text { clone } 1 \mathrm{aD} 3\end{array}$ & AY 800210 & 90 & 6 & & & & & & & & & \\
\hline & & $\mathrm{ARCH}-3$ & Unc archaeon clone 280NJ33E & AM072592 & 88 & 4 & & & & & & & & & \\
\hline & & $\mathrm{ARCH}-4$ & $\begin{array}{l}\text { Unc archaeon clone } \\
\text { MD2896-A116 }\end{array}$ & EU385665 & 92 & 2 & & & & & & & & & \\
\hline & & $\mathrm{ARCH}-5$ & Unc archaeon clone 280 NJ34E & AM072593 & 96 & 1 & & & & & & & & & \\
\hline & & $\mathrm{ARCH}-6$ & Unc archaeon clone 280 NJ34E & AM072593 & 92 & 1 & & & & & & & & & \\
\hline & & $\mathrm{ARCH}-7$ & $\begin{array}{l}\text { Unc euryarchaeote } \\
\text { clone } 1 \mathrm{aD} 3\end{array}$ & AY800210 & 92 & 1 & & & & & & & & & \\
\hline
\end{tabular}

Shown are the higher taxonomic grouping, name of the recovered phylotype (OTU: operational taxonomic unit, based on $98 \%$ similarity), closest BLAST hits (names, accession numbers, and similarity \%). The number of clones refers to the number of sequenced DGGE bands that were placed within that phylotype. Presence within the sapropel layers ( $\$ 1$ through 55 ) or the intercalating marls is indicated with black cells. Sequences found at WHOI are shown in separate columns. Phylotypes that were found in nontemplate controls are marked with an asterisk $\left(^{*}\right)$

Unc., uncultured; Sap, sapropel; i.s., Nonsapropelic intercalating sediment; e.c., extraction control; ntc, nontemplate control.

mays, which was only recovered from the intercalating marl between S3 and S4, represents a likely contamination even though this sequence was not recovered from the control PCRs.

\section{Dinoflagellate and haptophyte-related phylotypes}

Besides using general eukaryote primers to identify the most abundant eukaryote phylotypes present, we also used group-specific primers to target only partial $18 \mathrm{~S} \mathrm{rDNA}$ of past dinoflagellates and haptophytes. These more specific primers lowered the detection limit for their $18 \mathrm{~S}$ rDNA and resulted in the identification of additional phylotypes (Fig. 2).

The use of dinoflagellate-specific primers resulted in the identification of six phylotypes within sapropel S1 (Fig. 2). Only one sequence (MS_Dinol_01) was similar to a phylotype identified by the general eukaryote PCR assay (EUK-39). The most closely related sequence was also recovered from anoxic Black Sea sediments (DQ234288; Coolen et al., 2006) with the genus Pentapharsodinium as closest cultured relatives. The other five dinoflagellate phylotypes were not detected with the general eukaryote PCR assay. These additionally retrieved sequences all cluster within the dinoflagellate crown group, whereas the phylotypes from the general eukaryote PCR assay cluster with the more basal dinoflagellates (i.e. Syndiniales; Guillou et al., 2008).

The haptophyte-specific PCR assay resulted in the identification of five phylotypes within SI that were missed with the general PCR assay (Fig. 2B). The only phylotype that was recovered by both assays (EUK_23, MS_Hapl_02; Fig. 2B) was related to the marine alkenone-producing and calcifying haptophyte E. huxleyi. Another sequence of interest is MS_Hapl_01 with $99.5 \%$ sequence similarity to uncultivated Prymnesiophyte clones that, according to RNA stable isotopic probing (RNA-SIP) experiments, were capable of mixotrophic growth as predators of picocyanobacteria (Frias-Lopez et al., 2009). 


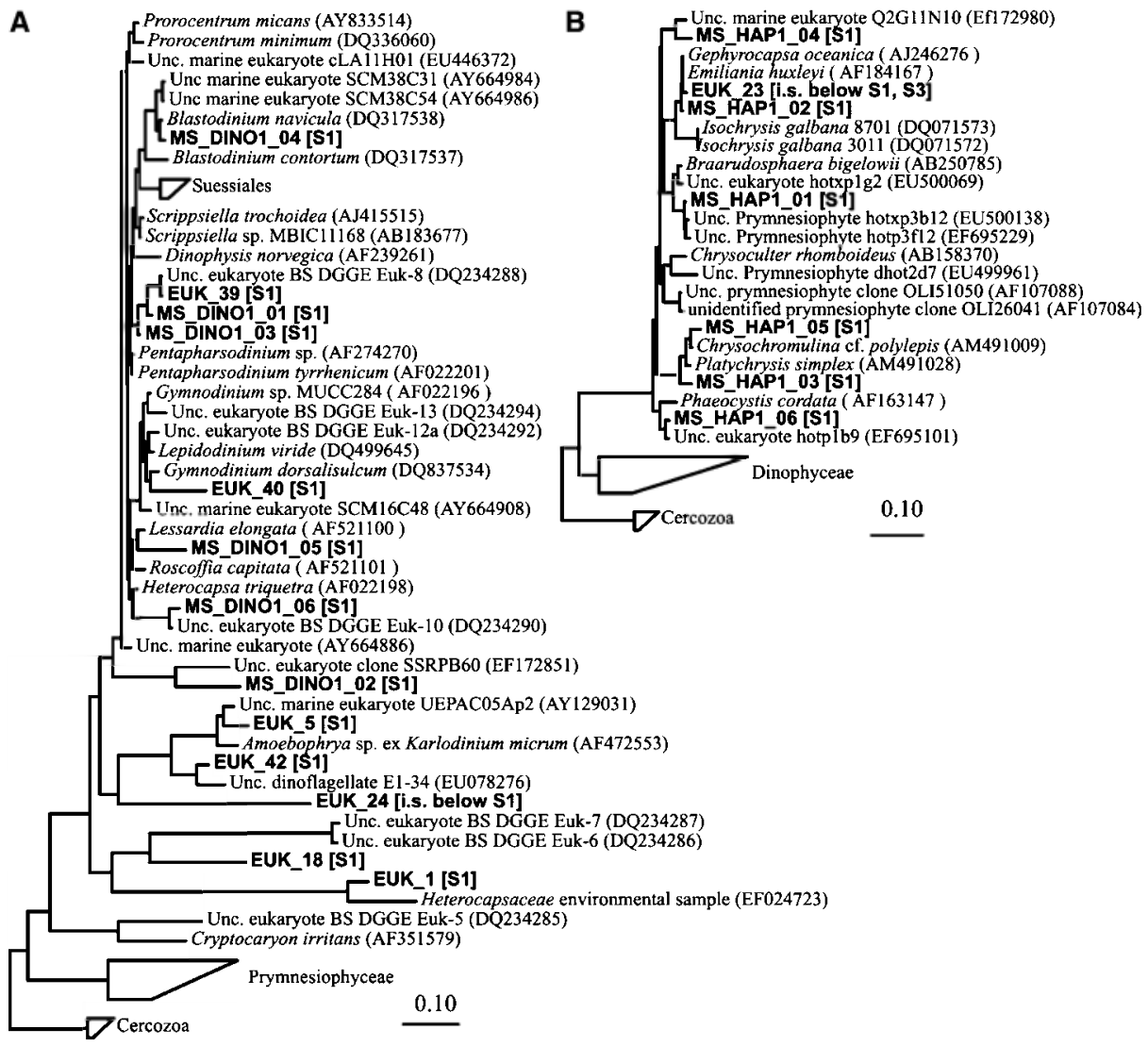

Fig. 2 Bayesian inferred phylogenetic trees showing the relationship between fossil 18S rDNA sequences found using group-specific PCR assays for haptophytes 'HAP' and dinoflagellates 'DINO', and sequences related to these taxonomic groups recovered with the general eukaryote PCR assay ('EUK'). Both trees were obtained in one single MrBayes run, and the subtrees of interest are shown separately. (A) Subtree with dinoflagellate sequences. (B) Subtree with haptophyte sequences. Phylotypes found in this study are shown in bold face. The sediments layers in which the unique phylotypes were found are indicated in square brackets, e.g. [S1]. Abbreviation: unc. (uncultured); i.s. (intercalating, $C_{\text {org }}$-depleted sediment).

\section{Biomarker lipids}

A parallel quantitative analysis of the sterol dinosterol (4a,23,24-trimethyl-5 $\alpha$-cholest-22E-en-3 $\beta$-ol) and long-chain alkenones was performed as a measure for the amount of biomass derived from dinoflagellates (Volkman, 2003 and references therein) vs. haptophytes (Marlowe et al., 1984) of the order Isochrysidales (most notably E. huxleyi). A comparable quantitative profile of DNA would be expected unless the fossil plankton DNA underwent extensive degradation with increasing sediment depth and age.

In general, the dinosterol and alkenone concentrations varied between 50 and $200 \mu \mathrm{g} \mathrm{g}^{-1} \mathrm{C}_{\text {org }}$ in the sapropels, with lowest concentrations in S1 (i.e. $\sim 50 \mu \mathrm{g} \mathrm{g}^{-1} \mathrm{C}_{\text {org }}$ ). Alkenone concentrations exceeded dinosterol concentrations in most samples, except in S1, where concentrations of both biomarkers were comparable (Fig. 1C). Lower, but still detectable concentrations were present in the intercalating sediments $\left(<10 \mu \mathrm{g} \mathrm{g}^{-1}\right.$ $\mathrm{C}_{\mathrm{org}}$; Fig. 1C). For clarity, only the concentration profile of the $\mathrm{C}_{37: 2}$ alkenone is shown in Fig. $1 \mathrm{C}$ to compare with the haptophyte $18 \mathrm{~S}$ rDNA data (Fig. $1 \mathrm{~F}$ ). Additional detected alkenones (i.e. $\mathrm{C}_{37: 3}$ and $\mathrm{C}_{38: 2}$ ) revealed a similar downcore trend.
To estimate the contribution of continental OM in our core, we determined the ratio between soil-derived branched tetracther lipids and marine-derived crenarchacol (i.e. BIT index; [Hopmans et al., 2004; ]). This BIT-index was low $(<0.1-0.2)$ within all sapropel layers, indicating that most of the sedimentary OM was of marine (pelagic) origin and that the terrestrial input into the Mediterranean was relatively limited during these intervals. Within sapropel S1, a slight decrease in BIT-index values from the bottom of the sapropel to the top was found, possibly reflecting the increased terrestrial run-off at the onset of sapropel formation. Intercalating marls occasionally showed high BIT-index values (up to 0.8 around $500 \mathrm{~cm}$ depth, Fig. 1B).

\section{DISCUSSION}

\section{Eukaryotic DNA in the Holocene eastern Mediterranean S1}

The presence of detectable amounts of preserved fossil $\sim 500$-bp-long partial $18 \mathrm{~S}$ rDNA fragments from organisms stemming from the ancient water column in core MS66PC 
was mainly restricted to the early Holocene sapropel \$1. For example, the use of general primers resulted in the detection of photoautotrophic protists such as the chlorophyte Nannochloris sp. (class Prasinophyceae). Such protists must originate from the ancient photic zone because they required light for photosynthesis, which is absent from the dark anoxic sediments (Coolen \& Overmann, 1998; Teske, 2007). The SI sediments also contained fossil DNA of metazoans such as calanoid copepods (i.e. zooplankton). Although copepods can live under extremely low oxygen conditions (Auel \& Verheye, 2007; Wishner et al., 2008), these species are unambiguously of pelagic origin. Copepods could serve as sensitive recorders of past salinity, temperature regimes, or change in currents, but they have been excluded from paleoenvironmental studies because their preserved morphological remains, merely resting eggs or cuticles, are often difficult to distinguish. However, fossil copepod DNA has recently been used to identify cryptic species in Holocene Antarctic lake sediments (Bissett et al., 2005) and the Black Sea (Coolen \& Shtereva, 2009) and offers potential to include copepods in future paleoenvironmental studies. A single occurrence of preserved DNA (Euk-17) from a benthic worm (Enteropneusta; Cameron et al., 2000), which cannot be identified microscopically because of the lack of fossilizing remains, is supportive for limited bioturbation that occurred during SI deposition (Basso et al., 2004; Löwemark et al., 2006).

The majority of the recovered sequences from the SI belong to the superphylum Alveolata (Tables 1 and 2). Many species of the Alveolata have complex lifestyles and can be autotrophic, heterotrophic, mixotrophic, and even parasitic (Stoecker et al., 1997; Stoecker, 1999). Many of the Alveolata phylotypes that were recovered from $S 1$ intervals using general primers (e.g. EUK-1 , -5, 18, -24, -42 in Fig. 2A) cluster with basal lineages related to dinoflagellates (i.e. Syndiniales; Guillou et al., 2008). Recent cultivation-independent molecular surveys revealed that many basal alveolate lineages can be found in sulfidic bottom waters of stratified aquatic settings (Alexander et al., 2009; Behnke et al., 2006; Coolen \& Shtereva, 2009; Dawson \& Pace, 2002; Edgcomb et al., 2009; López-García et al., 2003; Stoeck et al., 2007; Takishita et al., 2007). To date, the novel anoxic lineages are uncultured, and nothing is known about their physiological and environmental requirements or limitations (Kolodziej \& Stoeck, 2007; Teske, 2007). However, because the sequences found in S1 are related to Alveolata from anoxic, sulfidic waters, our sequences could be markers for such conditions during $\$ 1$ deposition.

Surprisingly, no sequences of phototrophic diatoms were recovered, although diatoms are often considered to be important species contributing to OM in sapropels (Kemp et al., 1999). Similarly, despite the presence of diagnostic long-chain alkenones, no haptophyte sequences were recovered from SI intervals using the general eukaryotic PCR assay
(Tables 1 and 2). The use of general primers often fails to detect important phyla (Potvin \& Lovejoy, 2009; Stoeck et al., 2006), which can be overcome by the use of more specific (group-specific) primers during PCR (Coolen et al., 2004; Richards \& Bass, 2005; Viprey et al., 2008). In our case, using primers targeting only haptophyte $18 \mathrm{~S}$ rDNA enabled the detection of the alkenone-producing calcified E. buxleyi in the S1 interval (MS_HAP1_02). Another interesting finding is phylotype MS_Hapl_01, which is related to uncultivated haptophytes that were not part of the nannofossil assemblage (Boere $e t a l ., 2011$ ) and which were experimentally shown to grow mixotrophically as predators of picocyanobacteria (Frias-Lopez et al., 2009), an adaptation that promotes growth in oligotrophic marine waters (Raven, 1997) such as most likely prevailed during early SI deposition (e.g. Principato et al, 2006).

\section{Eukaryote DNA in Pleistocene eastern Mediterranean sediment intervals}

The use of group-specific primers for dinoflagellates and haptophyte algae yielded reliable PCR products predominantly within the SI sapropel and rarely in the deeper sediments. In contrast, the concentration of diagnostic general lipid biomarkers of both plankton groups (i.e. dinosterol and long-chain alkenones) was higher in the deeper sapropels S3 through S5 than in the S1. This result, in addition to the fact that the majority of protist sequences were also recovered from the SI using general eukaryotic primers, suggests that most of the investigated protist DNA was degraded to smaller than 400 to 500-bp-long fragments between 10 and $80 \mathrm{ka} \mathrm{BP}$ and for that reason escaped amplification by PCR For analyzing fossil plankton DNA in sediments older than the Holocene and deposited under less favorable conditions, we therefore suggest targeting a shorter, hypervariable region of the $18 \mathrm{~S}$ rDNA such as the $\sim 130$-bp-long V9 region of $185 \mathrm{rDNA}$, which was recently introduced for amplicon 454 pyrosequencing (Amaral-Zettler et al., 2009).

Instead, fungi were among the most frequently sequenced partial $18 \mathrm{~S}$ rRNA genes from the deeper sediments. The ascomycete $P$. guilliermondii, which is closely related to phylotype FUNG-1 found in most sapropels as well as in the intercalating $\mathrm{C}_{\text {org }}$-depleted sediments, is a widespread facultative marine yeast (Bass et al., 2007; Gadanho \& Sampaio, 2005; Kutty \& Philp, 2008). Other recovered fungal phylotypes were related to obligate marine strains, notably Metschnikowa, Rbodosporidium, and Rbodotorula species (Kutty \& Philp, 2008). Marine fungi were until recently believed to comprise a minor part of the eukaryotic community in deep-sea environments (Bass et al., 2007), but their widespread occurrence was recently confirmed by several cultivation-independent molecular approaches (Alexander et al., 2009; Bass et al., 2007; Burgaud et al., 2009; Edgcomb et al., 2002, 2009, 2011; López-García et al., 2003; Takishita et al., 2006). It 
remains unclear whether the fungal DNA in core MS66PC is of ancient origin because marine fungi, including yeasts, may be growing actively in subsurface sediments (Damare et al., 2006; Edgcomb et al., 2011; Damare \& Raghukumar, 2008). On the other hand, fungi are capable of long-term preservation of their DNA in the form of spores (Lydolph et al., 2005), and the distribution of fungal spores in Pleistocene Indian Ocean deep-sea sediments has been linked to environmental changes in the overlying water column at the time of sediment deposition (Raghukumar et al., 2004). Alive or preserved, intact fungal DNA and that of prokaryotes could be part of the high molecular weight DNA size class in the up to 124-ka-old sediments as shown in Fig. S2. The use of fungal spores for paleoenvironmental reconstructions is in its infancy, but fossil DNA would be a useful alternate approach to escape cultivation bias associated with ancient preserved spores (Damare et al., 2006; Raghukumar et al., 2004).

Sequences from terrestrial plants were also more frequently recovered than sequences of marine protists in the Pleistocene sediments (Table 2), whereas the low BIT indices of all analyzed sapropels indicated that most of the buried OM was marine derived (Hopmans et al., 2004; Menzel et al., 2006). Therefore, the increased ratio in terrestrial plant vs. plankton DNA with increasing sediment depth and age suggests a preferred preservation of terrestrial plant DNA over marine plankton DNA. In particular, seeds and pollen, as the plant's reproductive organs, are intended for long-term DNA preservation and are often protected with a sturdy or lignified exocarp. The outer walls of pollen grains are extremely resistant to chemical and physical attack, and they might be indefinitely preserved in anaerobic sediments (Schlumbaum et al., 2008 and references therein). Pollen are thus considered to be an excellent source for DNA (Bennett \& Parducci, 2006; Parducci et al., 2005; Schlumbaum et al., 2008). For example, ancient plastid DNA has recently been recovered from up to 11000 -year-old pollen in lake sediments (Magyari et al., 2011; Parducci et al., 2005), and ancient plant DNA has also been extracted from enzymatically digested plant biomass in fossil feces (Poinar et al., 2001). In contrast, the majority of plankton species, including $85 \%$ of the dinoflagellates, do not form protective resting stages, and the majority of DNA in marine sediments was shown to be extracellular (Dell'Anno \& Danovaro, 2005), and therefore likely less well protected against (a)biotic degradation processes than DNA inside pollen grains.

Holocene and Pleistocene eastern Mediterranean sapropels obtained west of Greece were shown to contain between 20000 and 70000 pollen grains per gram sediment (e.g. Rossignol-Strick \& Paterne, 1999). It is to be expected that the pollen content in our core is also high because of the close proximity to the Nile as a source of terrestrial organic matter input. Some of the recovered terrestrial plant sequences are related to sequences from genera that occur in northern Africa or more broadly in tropical regions of the world such as $A l b i$ zia (Euk14), Lygodium (Euk31), and Lolium (Euk_16_mc). However, the relatively conserved 185 rDNA is not widely used as a suitable marker for plant barcoding. A more suitable marker for genus to species-level plant barcoding is the very short $(90 \mathrm{bp})$ chloroplast P6 loop within the tm $\mathrm{L}$ intron, which was recently used to study the diet of various herbivores from heavily degraded DNA isolated from feces (Valentini et al., 2009).

It is important to stress that paleoclimatic inferences based on the presence and identification of fossil plant gene sequences should be treated with caution because airborne pollen are considered to be a source of contamination during sampling and handling of the sediments (Boreson et al., 2004; Parducci et $a l$., 2005), and some researchers automatically excluded plant sequences from their analyses (Behnke et al., 2006; Stoeck et al., 2007; Viprey et al., 2008). On the other hand, the chance of contamination through airborne pollen in the middle of the Mediterranean Sea and inside a sealed container should have been minor in comparison to studies that involved ancient DNA from pollen recovered from lake sediments surrounded by forest (Parducci et al., 2005). More importantly, there was sufficient heterogeneity in the terrestrial plant DNA composition between sediment intervals, whereas the same DNA profile would be expected if the surface of our aseptically prepared core was contaminated with airborne pollen. By way of exception, the Zea mays sequence in the marl between S3 and S4 was most likely introduced from the corn-derived packing material used for the shipment of the PowerMax Soil DNA isolation kit buffer S5 (MoBio laboratories). With the exception of one sequence related to Picea (spruce; Euk_02_mc) found in the 'no template DNA' control at WHOI, the controls for contamination with plant DNA during DNA extraction and for the preparation of PCR mixtures at the NIOZ, where most of the samples were analyzed, remained negative for terrestrial plant DNA. Therefore, Pleistocene eastern Mediterranean sediments seem to represent an archive of higher plant DNA to study past vegetation changes. This would help palynologists to identify plant sources of difficult to classify pollen grains. Furthermore, the laborious pollen stratigraphic analysis could be minimized with prior knowledge about the expected species composition as revealed by a preliminary fossil higher plant DNA survey.

\section{Unexpected amplification of archaeal 165 rDNA}

Archaeal PCR products were nonspecifically recovered from all sapropel intervals as well as some of the intercalating marls with the two-step PCR approach. Despite the high number of cycles (42) involved, direct amplification with GC primers did not result in the nonspecific recovery of archaeal sequences. This high number of cycles was necessary to compensate for the lower PCR efficiency when using these GC-clamp primers. 
On the other hand, this approach was less sensitive because many more phylotypes were recovered from the samples analyzed with the two-step approach with eukaryotic primers at the NIOZ.

Other studies have observed the amplification of nontarget DNA bias in sediments from mud flats (Wilms et al., 2006), aquifers (Euringer \& Lueders, 2008), and deep-sea anoxic basins (Alexander et al., 2009; Jeon et al., 2008). Archaea are abundant in subsurface sediments (Biddle et al., 2006; Coolen et al., 2002; Inagaki et al., 2005), and prokaryotic 165 rDNA was shown to outnumber eukaryote $18 \mathrm{~S}$ rDNA by several orders of magnitude in Pleistocene Peru Margin sediments (Schippers et al., 2005; Schippers \& Neretin, 2006). For more reliable qPCR assays, especially when targeting low copy DNA, it is therefore important to reveal the identity of the amplified DNA through sequencing. In our study, the nonspecific co-amplification of archaeal 165 rDNA using general eukaryotic primers most likely resulted in an overestimation of the amount of preserved eukaryote $18 \mathrm{~S}$ rDNA.

\section{CONCLUSIONS}

Our results showed that 400 - to 500 -bp-long $18 \mathrm{~S}$ rDNA of planktonic (microbial) eukaryotes and zooplankton can be recovered from Holocene $C_{\text {org }}$-rich deep-sea subsurface sediments, but $18 \mathrm{~S}$ rDNA from plankton groups that were analyzed in detail (i.e. from haptophyte algae and dinoflagellates) was sporadically amplified with both general and groupspecific primers from sapropels deposited between 80 and $124 \mathrm{ka}$ ago. This was unexpected because of the coinciding presence of preserved diagnostic general lipid biomarkers for both algal groups with concentrations in the Pleistocene sapropels exceeding those measured in the Holocene S1. This suggests that the majority of the planktonic DNA was degraded into smaller than 400- to 500-bp-long fragments between $\sim 10$ and 80 ka after deposition and escaped amplification by PCR For analyzing fossil plankton DNA in sediments older than the Holocene and deposited under less favorable conditions, we suggest targeting a shorter, hypervariable region of the $18 \mathrm{~S} \mathrm{rDNA}$ such as the $\sim 130$-bp-long V9 region of $18 \mathrm{~S} \mathrm{rDNA}$, which was recently introduced for amplicon 454 pyrosequencing (Amaral-Zettler et al., 2009). Instead, the majority of the recovered $18 \mathrm{~S}$ rDNA sequences in the Pleistocene sediments were derived from marine fungi as well as terrestrial plants. However, most of the sedimentary OM was of marine rather than terrestrial origin according to the BIT index, which suggests a preferred degradation of $>10$-ka-old marine plankton DNA over terrestrial plant DNA. Higher plant DNA is protected against degradation inside fossil pollen grains and because contamination of our samples with foreign DNA was unlikely, the Pleistocene eastern Mediterranean sediments seem to represent an archive of ancient higher plant DNA. This would help palynologists to identify plant sources of difficult to classify pollen grains.
Furthermore, the laborious pollen stratigraphic analysis could be minimized with prior knowledge about the expected species composition as revealed by a preliminary fossil plant DNA survey. Resolving the past higher plant composition at up to genus or species-level taxonomic resolution would require further study and the use of faster evolving genes such as the short chloroplast P6 loop within the tm $\mathrm{L}$ intron. Lastly, the use of the two-step PCR approach to target low copy template ancient DNA was far more sensitive than the onestep PCR directly with GC primers, but this increased the chance of introducing PCR artifacts such as the nonspecific amplification of presumably abundant archaeal $16 \mathrm{~S} \mathrm{rDNA}$ or the specific amplification of low copy contaminants. For more reliable qPCR assays, especially when targeting low copy DNA, it is therefore important to determine the identity of the amplified DNA by sequencing.

\section{ACKNOWLEDGMENTS}

We would like to thank Alina Stadnitskaia, Shauna ní Flaithearta, and the captain and crew of the $\mathrm{R} / \mathrm{V}$ Pelagia for obtaining and subsampling the core. Marianne Baas, Jort Ossebaar, and Sanela Gusic are thanked for initial lipid analyses and $\mathrm{C}_{\text {org }}$ measurements, respectively. This work was supported by grants and prizes from the Netherlands Organization for Scientific Research (NWO Open Competition grant 813.03.001 and NWO-VENI grant 016.051.014 to M.J.L.C., Spinoza prize to J.S.S.D.) as well as financial support from the U.S. National Science Foundation grant number 0825020 to M.J.L.C.

\section{REFERENCES}

Alexander E, Stock A, Breiner HW, Behnke A, Bunge J, Yakimov MM, Stoeck T (2009) Microbial eukaryotes in the hypersaline anoxic L'Atalante deep-sea basin. Environmental Microbiology 11 , 360-381.

Amaral-Zettler LA, McCliment EA, Ducklow HW, Huse SM (2009) A method for studying protistan diversity using massively parallel sequencing of $V 9$ hypervariable regions of small-subunit ribosomal RNA genes. PLoS ONE 4, e6372.

Armbrust EV, Wieneke SG, McGillicuddy DJ, Olson RJ (2008) Phylogenetic diversity of nanoplankton in Sargasso Sea Eddies. p. 0 .

Auel H, Verheye HM (2007) Hypoxia tolerance in the copepod Calanoides carinatus and the effect of an intermediate oxygen minimum layer on copepod vertical distribution in the northern Benguela Current upwelling system and the Angola-Benguela Front. Journal of Experimental Marine Biology and Ecology 352, 234-243.

Bass D, Howe A, Brown N, Barton H, Demidova M, Michelle H, Li L, Sanders H, Watkinson SC, Willcock S, Richards TA (2007) Yeast forms dominate fungal diversity in the deep oceans. Proceedings of the Royal Society B-Biological Sciences 274, 3069-3077.

Basso D, Thomson J, Corselli C (2004) Indications of low macrobenthic activity in the deep sediments of the eastern Mediterranean Sea. Scientia Marina 68, 53-62.

Behnke A, Bunge J, Barger K, Breiner H-W, Alla V, Stoeck T (2006) Microeukaryote community patterns along an $\mathrm{O}_{2} / \mathrm{H}_{2} \mathrm{~S}$ gradient in 
a supersulfidic anoxic Fjord (Framvaren, Norway). Applied and Environmental Microbiology 72,3626-3636.

Bennett KD, Parducci L (2006) DNA from pollen: principles and potential. Holocene 16, 1031-1034.

Biddle JF, Lipp JS, Lever MA, Lloyd KG, Sørensen KB, Anderson R, Fredricks HF, Elvert M, Kelly TJ, Schrag DP, Sogin ML, Brenchley JE, Teske A, House CH, Hinrichs KU (2006) Heterotrophic Archaea dominate sedimentary subsurface ecosystems off Peru. Proceedings of the National Academy of Sciences USA 103, 3846-3851

Bissett A, Gibson JAE, Jarman SN, Swadling KM, Cromer L (2005) Isolation, amplification, and identification of ancient copepod DNA from lake sediments. Limnology Oceanography Methods $\mathbf{3}$, 533-542.

Boere AC, Abbas B, Rijpstra WIC, Versteegh GJM, Volkman JK, Sinninghe Damsté JS, Coolen MJL (2009) Late-Holocene succession of dinoflagellates in an Antarctic fjord using a multi-proxy approach: paleoenvironmental genomics, lipid biomarkers and palynomorphs. Geobiology 7, 265-281.

Boere AC, Rijpstra WI, de Lange GJ, Malinverno E, Sinninghe Damsté JS, Coolen ML (2011) Exploring preserved fossil dinoflagellate and haptophyte DNA signatures to infer ecological and environmental changes during deposition of sapropel S1 in the eastern Mediterranean. Paleoceanography 26, A2204.

Boreson J, Dillner AM, Peccia J (2004) Correlating bioaerosol load with PM2.5 and PM10cf concentrations: a comparison between natural desert and urban-fringe aerosols. Atmospheric Environment 38, 6029-6041.

Burgaud G, Le Calvez T, Arzur D, Vanderkoornhuyse P, Barbier G (2009) Diversity of culturable marine filamentous fungi from deepsea hydrothermal vents. Environmental Microbiology 11, 15881600 .

Cameron CB, Garey JR, Swalla BJ (2000) Evolution of the chordate body plan: new insights from phylogenetic analyses of deuterostome phyla. Proceedings of the National Academy of Sciences of the USA 97, 4469-4474.

Castradori D (1993) Calcareous nannofossils and the origin of eastern Mediterranean sapropels. Paleoceanography 8, 459-471.

Coolen MJL (2011) 7000 Years of Emiliania buxleyi viruses in the Black Sea. Science 333, 451-452.

Coolen ML, Overmann J (1998) Analysis of subfossil molecular remains of purple sulfur bacteria in a lake sediment. Applied and Environmental Microbiology 64, 4513-4521.

Coolen MJL, Overmann J (2007) 217 000-year-old DNA sequences of green sulfur bacteria in Mediterranean sapropels and their implications for the reconstruction of the paleoenvironment. Environmental Microbiology 9, 238-249.

Coolen MJ, Shtereva G (2009) Vertical distribution of metabolically active eukaryotes in the water column and sediments of the Black Sea. FEMS Microbiology Ecology 70, 525-539.

Coolen MI, Cypionka H, Sass AM, Sass H, Overmann J (2002) Ongoing modification of Mediterranean Pleistocene sapropels mediated by prokaryotes. Science 296, 2407-2410.

Coolen MJL, Muyzer G, Rijpstra WIC, Schouten S, Volkman JK, Sinninghe Damsté JS (2004) Combined DNA and lipid analyses of sediments reveal changes in Holocene haptophyte and diatom populations in an Antarctic lake. Earth and Planetary Science Letters 223, 225-239.

Coolen MJL, Boere A, Abbas B, Baas M, Wakeham SG, Sinninghe Damsté JS (2006) Ancient DNA derived from alkenone-biosynthesizing haptophytes and other algae in Holocene sediments from the Black Sea. Paleoceanography 21, 1-17.

Coolen ML, Volkman JK, Abbas B, Muyzer G, Schouten S, Sinninghe Damsté JS (2007) Identification of organic matter sources in sulfidic late Holocene Antarctic fjord sediments from fossil rDNA sequence analysis. Paleoceanography 22, pa2211.

Coolen MJL, Talbot HM, Abbas BA, Ward C, Schouten S, Volkman JK, Sinninghe Damsté JS (2008) Sources for sedimentary bacteriohopanepolyols as revealed by $165 \mathrm{SDNA}$ stratigraphy. Ennironmental Microbiology $10,1783-1803$.

Coolen MJL, Saenz JP, Giosan L, Trowbridge NY, Dimitrov P, Dimitrov D, Eglinton TI (2009) DNA and lipid molecular stratigraphic records of haptohyte succession in the Black Sea during the Holocene. Earth and Planetary Science Letters 284, 610-621.

Corinaldesi C, Beolchini F, Dell'Anno A (2008) Damage and degradation rates of extracellular DNA in marine sediments: implications for the preservation of gene sequences. Molecular Ecology 17 , 3939-3951.

Corinaldesi C, Barucca M, Luna GM, Dell'Anno A (2011) Preservation, origin and genetic imprint of extracellular DNA in permanently anoxic deep-sea sediments. Molecular Ecology 20, 642-654.

Cramp A, O'Sullivan G (1999) Neogene sapropels in the Mediterranean: a review. Marine Geology 153, 11-28.

Damare S, Raghukumar C (2008) Fungi and Macroaggregation in deep-sea sediments. Microbial Ecology 56, 168-177.

Damare S, Raghukumar S, Raghukumar S (2006) Fungi in deep-sea sediments of the Central Indian Basin. Deep Sea Research Part I: Oceanographic Research Papers 53, 14-27.

D'Andrea WJ, Lage M, Martiny JBH, Laatsch AD, Amaral-Zettler LA, Sogin ML, Huang Y (2006) Alkenone producers inferred from well-preserved 185 rDNA in Greenland lake sediments. Joumal of Geophysical Research 111, G03013-1-G03013-8.

Dawson SC, Pace NR (2002) Novel kingdom-level eukaryotic diversity in anoxic environments. Proceedings of the National Academy of Sciences of the USA 99, 8324-8329.

Dell'Anno A, Danovaro R (2005) Extracellular DNA plays a key role in deep-sea ecosystem functioning. Science 309, 2179.

Edgcomb VP, Kysela DT, Teske A, Gomez AD, Sogin ML (2002) Benthic eukaryotic diversity in the Guaymas Basin hydrothermal vent environment. Proceedings of the National Academy of Sciences of the USA 99, 7658-7662.

Edgcomb VP, Orsi W, Leslin C, Epstein SS, Bunge J, Jeon S, Yakimov MM, Behnke A, Stoeck T (2009) Protistan community patterns within the brine and halocline of deep hypersaline anoxic basins in the eastern Mediterranean Sea. Extremophiles 13, 151-167.

Edgcomb VP, Beaudoin D, Gast R, Biddle JF, Teske A (2011) Marine subsurface eukaryotes, the fungal majority. Environmental Microbiology $13,172-183$.

Emeis K-C, Schulz H, Struck U, Rossignol-Strick M, Erlenkeuser H, Howell MW, Kroon D, Mackensen A, Ishizuka S, Oba T, Sakamoto T, Koizumi I (2003) Eastern Mediterranean surface water temperatures and $\delta^{18} \mathrm{O}$ composition during deposition of sapropels in the late Quaternary. Paleoceanography 18, 5-1-5-18.

Epp LS, Stoof KR, Trauth MH, Tiedemann R (2010) Historical genetics on a sediment core from a Kenyan lake, intraspecific genotype turnover in a tropical rotifer is related to past environmental changes. Joumal of Paleolimnology 43, 939-954.

Euringer K, Lueders T (2008) An optimised PCR/T-RFLP fingerprinting approach for the investigation of protistan communities in groundwater environments. Joumal of Microbiological Methods 75 , 262-268.

Fogel GB, Collins CR, Li J, Brunk CF (1999) Prokaryotic genome size and SSU rDNA copy number, Estimation of microbial relative abundance from a mixed population. Microbial Ecology $\mathbf{3 8}$, 93-113. 
Frias-Lopez J, Thompson A, Waldbauer J, Chisholm SW (2009) Use of stable isotope-labelled cells to identify active grazers of picocyanobacteria in ocean surface waters. Environmental Microbiology $11,512-525$.

Gadanho M, Sampaio JP (2005) Occurrence and diversity of yeasts in the Mid-Atlantic ridge hydrothermal fields near the Azores Archipelago. Microbial Ecology 50, 408-417.

Guillou L, Viprey M, Chambouvet A, Welsh RM, Kirkham AR, Massana R, Scanlan DJ, Worden AZ (2008) Widespread occurrence and genetic diversity of marine parasitoids belonging to Syndiniales (Alveolata). Environmental Microbiology 10, 33493365 .

Hopmans EC, Weijers JWH, Schefuß E, Herfort L, Sinninghe Damsté JS, Schouten S (2004) A novel proxy for terrestrial organic matter in sediments based on branched and isoprenoid tetraether lipids. Earth and Planetary Science Letters 224, $107-116$

Inagaki F, Okada H, Tsapin AI, Nealson KH (2005) The paleome: a sedimentary genetic record of past microbial communities. Astrobiology 5, 141-153.

Janse I, Bok J, Zwart G (2004) A simple remedy against artifactual double bands in denaturing gradient gel electrophoresis. Joumal of Microbiological Methods 57, 279-281.

Jeon S-O, Ahn T-S, Hong S-H (2008) A novel archaeal group in the phylum Crenarchaeota found unexpectedly in an eukaryotic survey in the Cariaco Basin. Joumal of Microbiology 46, 34-39.

Kemp AES, Pearce RB, Koizumi I, Pike J, Rance SJ (1999) The role of mat-forming diatoms in the formation of Mediterranean sapropels. Natuve 398, 57-61.

Klappenbach JA, Saxman PR, Cole JR, Schmidt TM (2001) rmdb: the ribosomal RNA operon copy number database. Nucleic Acids Research 29, 181-184.

Kolodziej K, Stoeck T (2007) Cellular identification of a novel uncultured marine stramenopile (MAST-12 clade) small-subunit rRNA gene sequence from a Norwegian estuary by use of fluorescence in situ hybridization-scanning electron microscopy. Applied and Environmental Microbiology 73, 2718-2726.

Kutty SN, Philp R(2008) Marine yeasts - a review. Yeast 25, 465-483.

LaJeunesse TC, Lambert G, Andersen RA, Coffroth MA, Galbraith DW (2005) Symbiodinium (Pyrrhophyta) genome sizes (DNA content) are smallest among dinoflagellates. Journal of Phycology $41,880-886$.

de Lange GJ, Thomson J, Reitz A, Slomp CP, Principato MS, Erba E, Corselli C (2008) Synchronous basin-wide formation and redoxcontrolled preservation of a Mediterranean sapropel. Nature Geoscience $1,606-610$.

López-García P, Philippe H, Gail F, Moreira D (2003) Autochthonous eukaryotic diversity in hydrothermal sediment and experimental microcolonizers at the Mid-Atlantic Ridge. Proceedings of the National Academy of Sciences of the USA 100,697-702.

Lorenz MG, Wackernagel W (1987) Adsorption of DNA to sand and variable degradation rates of adsorbed DNA. Applied and Environmental Microbiology 53, 2948-2952.

Löwemark L, Lin Y, Chen HF, Yang TN, Beier C, Werner F, Lee CY, Song SR, Kao SJ (2006) Sapropel burn-down and ichnological response to late Quaternary sapropel formation in two similar to $400 \mathrm{ky}$ records from the eastern Mediterranean Sea. Palareggeography Palacoclimatology Palaeoecology 239, 406-425.

Ludwig W, Strunk O, Westram R, Richter L, Meier H, Yadhukumar, Buchner A, Lai T, Steppi S, Jobb G, Förster W, Brettske I, Gerber S, Ginhart AW, Gross O, Grumann S, Hermann S, Jost R, König A, Liss T, Liißmann R, May M, Nonhoff B, Reichel B, Strehlow R, Stamatakis A, Stuckmann N, Vilbig A, Lenke M, Ludwig T, Bode
A, Schleifer K-H (2004) ARB: a software environment for sequence data. Nucleic Acids Research 32, 1363-1371.

Lydolph MC, Jacobsen J, Arctander P, Gilbert MTP, Gilichinsky DA, Hansen AJ, Willerslev E, Lange L (2005) Beringian paleoccology inferred from permafrost-preserved fungal DNA. Applied and Environmental Microbiology 71, 1012-1017.

Magyari E, Major A, Balint M, Nedli J, Braun M, Racz I, Parducci L (2011) Population dynamics and genetic changes of Picea abies in the South Carpathians revealed by pollen and ancient DNA analyses. BMC Evolutionary Biology 11, 66 .

Manske AK, Henßge U, Glaeser J, Overmann J (2008) Subfossil 165 rRNA gene sequences of green sulfur bacteria in the Black Sea and their implications for past photic zone anoxia. Applied and Environmental Microbiology 74, 624-632.

Marlowe IT, Brassell SC, Eglinton G, Green JC (1984) Long chain unsaturated ketones and esters in living algae and marine sediments. Organic Geochemistry 6, 135-141.

Marret F, Zonneveld KAF (2003) Atlas of modem organic-walled dinoflagellate cyst distribution. Review of Palaeobotany and Palynology $125,1-200$.

Menzel D, Hopmans EC, Schouten S, Sinninghe Damsté JS (2006) Membrane tetraether lipids of planktonic Crenarchaeota in Pliocene sapropels of the eastern Mediterranean Sea. Palacogeography, Palaeoclimatology, Palaeoecology $239,1-15$.

Muyzer G, de Waal EC, Uitterlinden AG (1993) Profiling of complex microbial populations by denaturing gradient gel electrophoresis analysis of polymerase chain reaction-amplified genes coding for $16 S$ rRNA. Applied and Enpironmental Microbiology 59,695 700 .

Negri A, Ferretti A, Wagner T, Meyers PA (2009) Phanerozoic organic-carbon-rich marine sediments: Overview and future research challenges. Palaeogeography Palaeoclimatology Palaeoccology $273,218-227$.

Nguyen TH, Elimelech M (2007) Adsorption of plasmid DNA to a natural organic matter-coated silica surface, Kinetics, conformation, and reversibility. Langmuir 23, 3273-3279.

Panieri G, Lugli S, Manzi V, Roveri M, Schreiber BC, Palinska KA (2010) Ribosomal RNA gene fragments from fossilized cyanobac teria identified in primary gypsum from the late Miocene, Italy Geobiology 8, 101-111

Parducci L, Suyama Y, Lascoux M, Bennett KD (2005) Ancient DNA from pollen: a genetic record of population history in Scots pine. Molecular Ecology 14, 2873-2882.

Peters KE, Walters CC, Moldowan JM (2005) The Biomarker Guide: Biomarkers and Isotopes in Petroleum Exploration and Earth History. Cambridge University Press, New York.

Pietramellara G, Ascher J, Borgogni F, Ceccherini MT, Guerri G, Nannipieri P (2009) Extracellular DNA in soil and sediment: fate and ecological relevance. Biology and Fertility of Soils 45, 219235.

Poinar HN, Kuch M, Sobolik KD, Barnes I, Stankiewicz AB, Kuder T, Spaulding WG, Bryant VM, Cooper A, Paabo S (2001) A molecular analysis of dietary diversity for three archaic Native Americans. Procedings of the National Academy of Sciences of the USA, 98, $4317-4322$.

Poly F, Chenu C, Simonet P, Rouiller J, Monrozier LJ (2000) Differences between linear chromosomal and supercoiled plasmid DNA in their mechanisms and extent of adsorption on clay minerals. Langmuir 16, 1233-1238.

Potvin M, Lovejoy C (2009) PCR-based diversity estimates of artificial and environmental 185 rRNA gene libraries. Joumal of Eukaryotic Microbiology 56, 174-181. 
Principato MS, Crudeli D, Ziveri P, Slomp CP, Corselli C, Erba E, de Lange GJ (2006) Phyto- and zooplankton paleofluxes during the deposition of sapropel SI (eastern Mediterranean): biogenic carbonate preservation and paleoecological implications. Palaeogeography, Palaeoclimatology, Palaeoecology 235, 8-27.

Pruesse E, Quast C, Knittel K, Fuchs BM, Ludwig WG, Peplies J, Glöckner FO (2007) SILVA: a comprehensive online resource for quality checked and aligned ribosomal RNA sequence data compatible with ARB. Nucleic Acids Research 35, 7188-7196.

Raghukumar C, Raghukumar S, Sheelu G, Gupta SM, Nagender Nath B, Rao BR (2004) Buried in time: culturable fungi in a deepsea sediment core from the Chagos Trench, Indian Ocean. DeepSea Research I 51, 1759-1768.

Raven JA (1997) Phagotrophy in phototrophs. Limnology and Oceanography 42, 198-205.

Reid VA, Carvalho GR, George DG (2000) Molecular genetic analysis of Daphnia in the English Lake District, species identity, hybridisation and resting egg banks. Freshwater Biology 44, 247-253.

Reitz A, Thomson J, de Lange GJ, Hensen C (2006) Source and development of large manganese enrichments above eastern Mediterranean sapropel S1. Paleoceanograpby 21, PA3007.

Richards TA, Bass D (2005) Molecular screening of free-living microbial eukaryotes: diversity and distribution using a meta-analysis. Current Opinion in Microbiology 8, 240-252.

de Rijk S, Hayes A, Rohling EJ (1999) Eastern Mediterranean sapropel S1 interruption: an expression of the onset of climate determination around $7 \mathrm{ka} \mathrm{BP.} \mathrm{Marine} \mathrm{Geology} \mathrm{153,} \mathrm{337-343.}$

Rohling EJ (1994) Review and new aspects concerning the for mation of eastern Mediterranean sapropels. Marine Geology $122,1-28$.

Romanowski G, Lorenz MG, Wackernagel W (1991) Adsorption of plasmid DNA to mineral surfaces and protection against DNase I. Applied and Environmental Microbiology 57, 1057-1061.

Rossignol-Strick M, Paterne M (1999) A synthetic pollen record of the eastern Mediterranean sapropels of the last $1 \mathrm{Ma}$, implications for the time-scale and formation of sapropels. Marine Geology 153, 221-237.

Sáez AG, Probert I, Young JR, Edvardsen B, Eikrem W, Medlin LK (2004) A review of the phylogeny of the Haptophyta. In Coccolithophores. From Molecular Processes to Global Impact (eds Thierstein HR, Young JR). Springer Verlag, Berlin, 251-269.

Schippers A, Neretin LN (2006) Quantification of microbial communities in near-surface and deeply buried marine sediments on the Peru continental margin using real-time PCR Environmental Microbiology 8, 1251-1260.

Schippers A, Neretin LN, Kallmeyer J, Ferdelman TG, Cragg BA, Parkes RJ, Jørgensen BB (2005) Prokaryotic cells of the deep sub-seafloor biosphere identified as living bacteria. Nature 433, 861-864.

Schloss PD, Handelsman J (2005) Introducing DOTUR, a computer program for defining operational taxonomic units and estimating species richness. Applied and Environmental Microbiology 71, 1501-1506.

Schlumbaum A, Tensen M, Jaenicke-Despres V (2008) Ancient plant DNA in archacobotany. Vegetation History and Archaeobotany 17, 233-244.

Stoeck T, Epstein S (2003) Novel eukaryotic lineages inferred from small-subunit rRNA analyses of oxygen-depleted marine environments. Applied and Environmental Microbiology 69, 2657-2663.

Stoeck T, Hayward B, Taylor GT, Varela R, Epstein SS (2006) A mul tiple PCR-primer approach to access the microeukaryotic diversity in environmental samples. Protist 157, 31-43.

Stoeck T, Zuendorf A, Breiner H-W, Behnke A (2007) A molecular approach to identify active microbes in environmental eukaryote clone libraries. Microbial Ecology 53, 328-339.
Stoecker DK (1999) Mixotrophy among dinoflagellates. Joumal of Eukaryotic Microbiology 46, 397-401.

Stoecker DK, Gustafson DE, Merrell JR, Black MMD, Baier CT (1997) Excystment and growth of chrysophytes and dinoflagellates at low temperatures and high salinities in Antarctic Sea-ice. Journal of Phycology 33, 585-595.

Takishita K, Miyake H, Kawato M, Maruyama T (2005) Genetic diversity of microbial eukaryotes in anoxic sediment around fuma roles on a submarine caldera floor based on the small-subunit rDNA phylogeny. Extremophiles 9, 185-196.

Takishita K, Tsuchiya M, Reimer JD, Maruyama T (2006) Molecular evidence demonstrating the basidiomycetous fungus Cryptococous curvatus is the dominant microbial eukaryote in sediment at the Kuroshima Knoll methane seep. Extremophiles $10,165-169$.

Takishita K, Tsuchiya M, Kawato M, Oguri K, Kitazato H, Maruyama $\mathrm{T}$ (2007) Genetic diversity of microbial eukaryotes in anoxic sediment of the saline meromictic lake Namako-ike (Japan): On the detection of anaerobic or anoxic-tolerant lineages of eukaryotes. Protist 158, 51-64.

Teske A (2007) Enigmatic Archaeal and Eukaryotic Life at Hydrothermal Vents and in Marine Subsurface Sediments. In Algae and Cyanobacteria in Extreme Environments (ed Seckbach J), Springer, Netherlands, 519-533.

Theroux S, D'Andrea WJ, Toney J, Amaral-Zettler L, Huang YS (2010) Phylogenetic diversity and evolutionary relatedness of alkenone-producing haptophyte algae in lakes, Implications for conti nental paleotemperature reconstructions. Earth Planetary Science Letters 300, 311-320.

Valentini A, Miquel C, Nawaz MA, Bellemain E, Coissac E, Pompanon F, Gielly L, Cruaud C, Nascetti G, Wincker P, Swenson JE, Taberlet $\mathrm{P}(2009)$ New perspectives in diet analysis based on DNA barcoding and parallel pyrosequencing, the trnL approach. Molecular Ecology Resources 9, 51-60.

Viprey M, Guillou L, Ferreol M, Vaulot D (2008) Wide genetic diversity of picoplanktonic green algae (Chloroplastida) in the Mediterranean Sea uncovered by a phylum-biased PCR approach. Environmental Microbiology 10, 1804-1822.

Volkman JK (2003) Sterols in microorganisms. Applied Microbiology and Biotechnology 60, 495-506.

Volkman JK, Barrett SM, Blackburn SI, Mansour MP, Sikes EL, Gelin F (1998) Microalgal biomarkers: a review of recent research developments. Organic Geochemistry 29, 1163-1179

Von Wintzingerode F, Göbel UB, Stackebrandt E (1997) Determina tion of microbial diversity in environmental samples: pitfalls of PCR-based rRNA analysis. FEMS Microbiology Reviews 21, 213229.

Wilms R, Sass H, Kõpke B, Köster H, Cypionka H, Engelen B (2006) Specific bacterial, archaeal, and eukaryotic communities in tidal-flat sediments along a vertical profile of several meters. Applied and Environmental Microbiology 72, 2756-2764.

Wishner KF, Gelfman C, Gowing MM, Outram DM, Rapien M, Williams RL (2008) Vertical zonation and distributions of calanoid copepods through the lower oxycline of the Arabian Sea oxygen minimum zone. Progress in Oceanography 78, 163-191.

Zhu F, Massana R, Not F, Marie D, Vaulot D (2005) Mapping of picoeucaryotes in marine ecosystems with quantitative PCR of the $18 \mathrm{~S}$ rRNA gene. FEMS (Federation of European Microbiological Societies) Microbiology - Ecology 52, 79 92.

Zonneveld KAF, Versteegh GJM, De Lange GJ (2001) Palaeopro ductivity and post-depositional aerobic organic matter decay reflected by dinoflagellate cyst assemblages of the Eastern Mediterranean S1 sapropel. Marine Geology 172, 181-195. 


\section{SUPPORTING INFORMATION}

Additional Supporting Information may be found in the online version of this article:

Fig. S1. Map of the Mediterranean Sea showing the location of core MS66PC.

Fig. S2. Agarose gel with total DNA extracts from selected intervals spanning sapropels $\mathrm{S1}, \mathrm{S3}, \mathrm{S4}$, and $\mathrm{S} 5$ as well as oxidized $\mathrm{C}_{\text {org }}$-poor intercalating sediments (i.s.)
Table S1. PCR assay specifications, including name and sequence of used primers, $E$. coli position of the primers, the amplicon size, annealing temperatures $\left(T_{a}\right)$ used in the analyses, target phylogenetic group and references where the primers were first described.

Please note: Wiley-Blackwell are not responsible for the content or functionality of any supporting materials supplied by the authors. Any queries (other than missing material) should be directed to the corresponding author for the article. 